\title{
Eocene relatives of cod icefishes (Perciformes: Notothenioidei) from Seymour Island, Antarctica
}

\author{
Małgorzata BIEŃKOWSKA-WASILUK ${ }^{1, *}$, Niels BONDE ${ }^{2,3}$, Peter Rask MØLLER ${ }^{4}$ \\ and Andrzej GAŹDZICKI ${ }^{5}$ \\ 1 Faculty of Geology, University of Warsaw, Żwirki i Wigury 93, 02-089 Warszawa, Poland \\ 2 Institute of Geography and Geology, University of Copenhagen, Voldgade 10, DK-1350 Copenhagen K, Denmark \\ 3 Fur Museum, Nederby, DK-7884 Fur, Denmark \\ 4 Natural History Museum of Denmark, University of Copenhagen, Universitetsparken 15, DK-2100 Copenhagen $\varnothing$, \\ Denmark \\ 5 Institute of Paleobiology, Polish Academy of Sciences, Twarda 51/55, 00-818 Warszawa, Poland
}

Bieńkowska-Wasiluk M., Bonde N., Møller P.R. and Gaździcki A. (2013) Eocene relatives of cod icefishes (Perciformes: Notothenioidei) from Seymour Island, Antarctica. Geological Quarterly, 57 (4): 567-582, doi: 10.7306/gq.1112

Fragmentary skull bones and vertebra from the Upper Eocene La Meseta Formation on Seymour (Marambio) Island, Antarctic Peninsula have been described as gadiform fishes, informally named "Mesetaichthys". Here we describe jaws as Mesetaichthys jerzmanskae n. gen. and n. sp., and refer this taxon to the perciform suborder Notothenioidei. This group is almost unknown as fossils. Similarities to the living, "primitive" nototheniid Dissostichus eleginoides are indicated in the dentition. Gadiform evolution in the Paleocene-Eocene is discussed, and the possibility of a correlation between the origin and evolution of notothenioids in connection with the deterioration of the climate in Antarctica during the Late Eocene-Oligocene is concluded.

Key words: Notothenioids, cod icefishes, Eocene, Seymour Island, Antarctica.

\section{INTRODUCTION}

Some fragmentary fish fossils from the upper La Meseta Formation (Upper Eocene) of Seymour Island (Isla Vicecomodoro Marambio), West Antarctica (Fig. 1), have been referred to Gadiformes by Jerzmańska and Świdnicki (1992). We intend to show that these fishes are the almost only known fossil representatives of cod icefishes' relatives, the perciform suborder Notothenioidei. Large jaw fragments are described as Mesetaichthys jerzmanskae n. gen. and n. sp.

The palaeontological data provides new insights into the Antarctic Eocene fish communities, and the origin of cod icefishes, and the opportunity to relate their evolution to the climatic changes during the Late Eocene to Pleistocene, recalling that this group, today is found dominating in the Southern Ocean, and is clearly adapted to cold waters.

The studied specimens were collected by A. Gaździcki and A. Tatur during the Argentine-Polish Field Party on Seymour Is-

\footnotetext{
*Corresponding author, e-mail: m.wasiluk@uw.edu.pl
}

Received: March 8, 2013; accepted: June 3, 2013; first published online: 8 July, 2013 land in the austral summer of 1991-1992. The collection comprises 45 specimens and is housed at the Institute of Paleobiology, Polish Academy of Sciences, Warszawa under catalogue number ZPAL P.V./1-45; all from the locality ZPAL 3, Telm7, uppermost Eocene (Figs. 2 and 3).

We provide descriptions of the jaw fragments (part dentaries and dermarticulars - "angulars" and premaxillaries), a basioccipital and isolated vertebrae previously informally named by Jerzmańska and Świdnicki (1992) as "Mesetaichthys". There are four premaxillae (ZPAL P.V./1-4), 12 dentary fragments (ZPAL P.V./5-16), seven dermarticulars (ZPAL P.V./17-23), a basioccipital (ZPAL P.V./24), and 21 vertebrae (ZPAL P.V./25-45).

\section{GEOLOGICAL AND STRATIGRAPHICAL SETTING}

The Eocene La Meseta Formation, which crops out in the northeastern portion of Seymour Island (Fig. 1), is a 720 m thick sequence of richly fossiliferous, shallow-marine, deltaic and/or estuarine poorly consolidated clastic strata (Figs. 2 and 3), accumulated within an incised valley (Sadler, 1988; Porębski, 1995; Marenssi et al., 1998; Marenssi, 2006; Tatur et al., 2011). The formation preserves an exceptional record of a shal- 


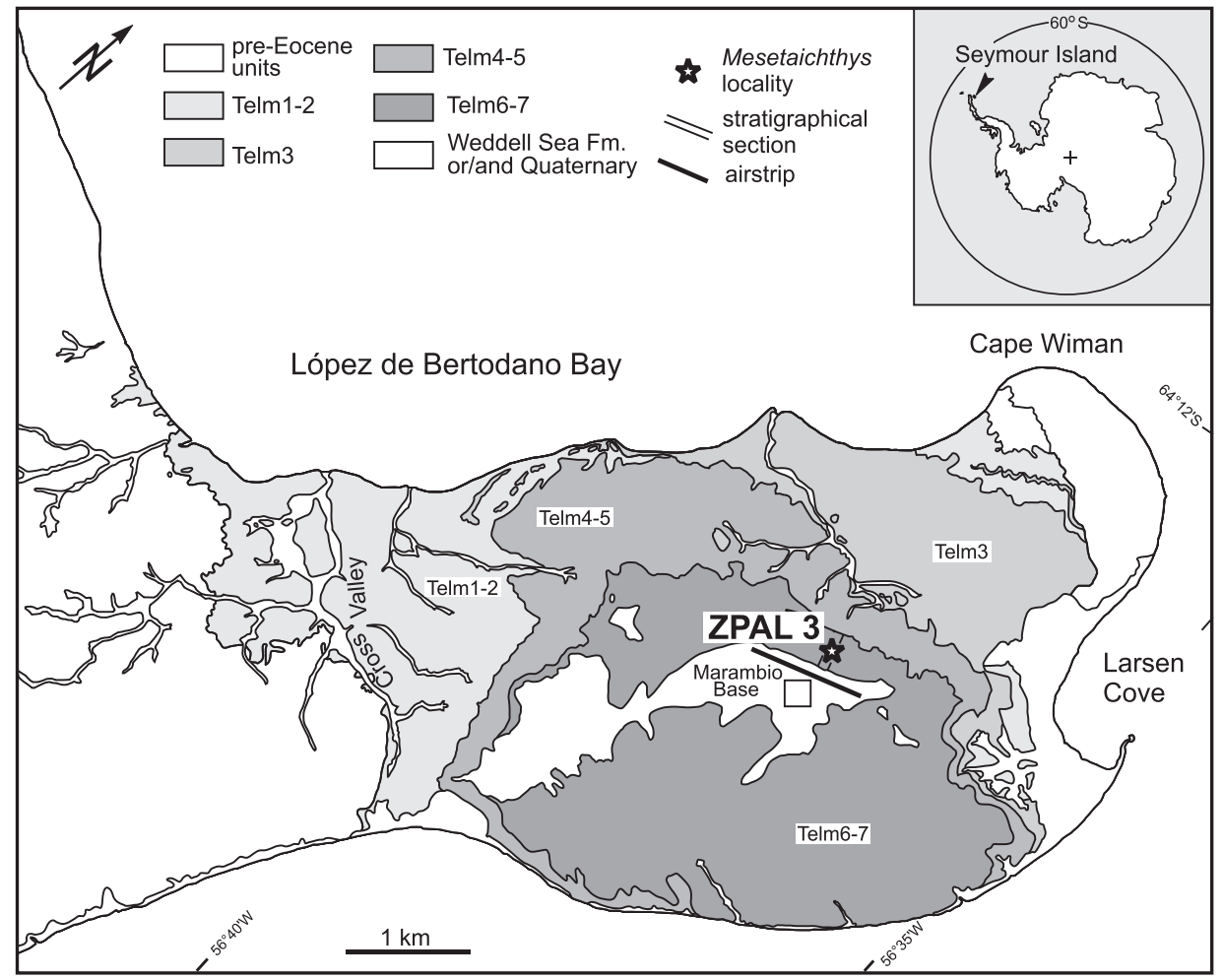

Fig. 1. Geological sketch map of the northern part of Seymour Island (simplified from Sadler, 1988) showing the locality ZPAL 3 where specimens Mesetaichthys jerzmanskae n. gen. and $\mathrm{n}$. sp. were collected

low-marine ecosystem (Feldmann and Woodburne, 1988; Stilwell and Zinsmeister, 1992; Gaździcki, 1996, 1998, 2001; Dzik and Gaździcki, 2001; Francis et al., 2006; Uchman and Gaździcki, 2006; Ivany et al., 2008; Gaździcki and Majewski, 2012).

Sadler (1988: fig. 1) identified seven numbered lithological units (Telm1-Telm7) within the formation, and this subdivision is accepted here (Fig. 2). For different subdivision schemes and their stratigraphical correlation see Elliott and Trautman (1982), Marenssi et al. (1998: fig. 4) and Marenssi (2006: fig. 5). The Mesetaichthys-bearing strata recognized within Telm7 (Figs. 2 and 3) consists of about $3 \mathrm{~m}$ thick fine grained green-gray sandstone, mudstone and shell beds. These strata contain the studied fish Mesetaichthys, the isocrinid Metacrinus fossilis (Rasmussen, 1979; Baumiller and Gaździcki, 1996: fig. 2), and the bivalves Hiatella and Mya (Fig. 2). It is probably the same horizon in which the fish vertebra described by Jerzmańska (1988: fig. 1) were found. In this part of the formation were also found two large "land-birds" (Case et al., 1987; Tambussi et al., 1994; Case, 2006; Cenizo, 2012), numerous bones of penguins (Simpson, 1971; Myrcha et al., 2002; Jadwiszczak, 2006, 2009, 2010, 2012; Jadwiszczak and Mörs, 2011) and whale remains (Borsuk-Białynicka, 1988; Mitchell, 1989; Fostowicz-Frelik, 2003). Myrcha et al. (2002: fig. 2) and Tambussi et al. (2006: tables 3,4$)$ summarized the invertebrates and vertebrates of the Telm7 (= Submeseta Allomember).

The Mesetaichthys-bearing strata (ZPAL 3: GPS position: S 6414'13.197', W 56 $38^{\prime} 12.014^{\prime \prime}$, 157 m a.s.l.; see Fig. 3) can be correlated with the Submeseta Allomember (36.0-34.2 Ma - see Marenssi, 2006: fig. 5) and the Anthropornis nordenskjoeldi Biozone (Tambussi et al., 2006: fig. 2b; see also Jadwiszczak, 2006). The age of the top of the La Meseta Fm. (Telm 7) is dated as 34.2 Ma, close to the Eocene-Oligocene boundary (Marenssi, 2006).
The geochemical analyses made on the fossil bivalve shells from the La Meseta Formation suggest a climatic cooling event during the time of deposition of the uppermost part of the formation (Gaździcki et al., 1992; Dingle et al., 1998; Ivany et al., 2006, 2008; Cione et al., 2007; Francis et al., 2009; Błażejowski et al., 2010). This is correlated with the first Cenozoic glaciation of Antarctica and with the opening of the Drake Passage at the Eocene-Oligocene boundary (Zachos et al., 2001; Birkenmajer et al., 2005). The upper boundary of the Telm7 is an unconformity with the Late Miocene Hobbs Glacier Formation (Marenssi et al., 2010) or the post-Late Pliocene Weddell Sea Formation (Fig. 2; Gaździcki et al., 2004).

\section{NOTOTHENIOIDS FROM THE LA MESETA FORMATION}

Notothenioids are the dominant and most diverse fishes around Antarctica today (Eastman, 2000). One would probably expect to find this group in the Paleogene, especially in the Eocene La Meseta Formation on Seymour Island, the only known marine strata with fossil fishes in Antarctica (Woodward, 1908; Welton and Zinsmeister, 1980; Grande and Eastman, 1986; Feldmann and Woodburne, 1988; Jerzmańska, 1988, 1991; Ward and Grande, 1991; Eastman and Grande, 1991; Long, 1991, 1992a, b, c; Jerzmańska and Świdnicki, 1992; Cione et al., 1994, 2001; Crame, 1994; Cione and Reguero, 1994, 1995, 1998; Doktor et al., 1988, 1996; Woodburne and Case, 1996; Reguero et al., 2002; Kriwet and Gaździcki, 2003; Kriwet, 2005; Kriwet and Hecht, 2008). Woodward (1908) identified some isolated vertebrae as Notothenia, but their current taxonomical status remains unclear (Grande and Eastman, 1986; Eastman and Grande, 1989). 
North Section

(Sadler, 1988)

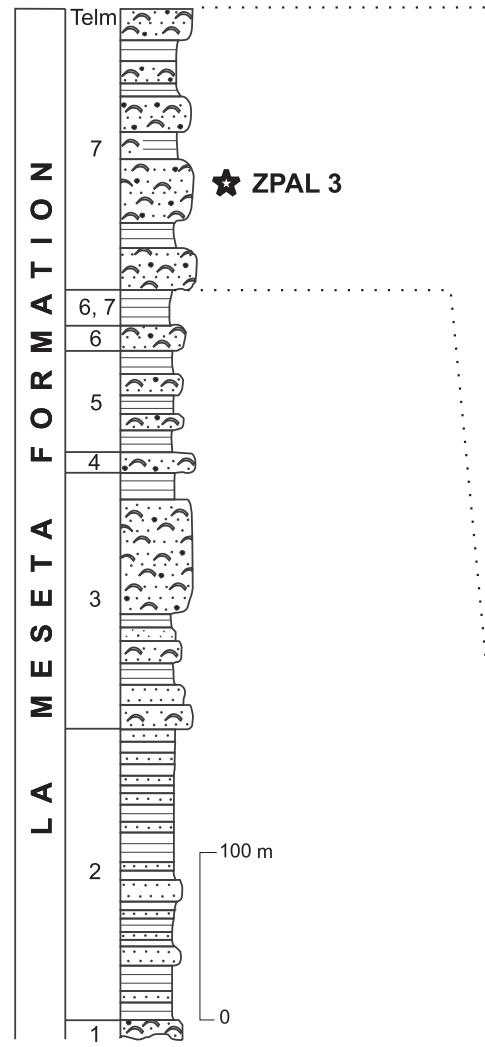

$\star$ ZPAL 3 Mesetaichthys locality

OCCURRENCE OF VERTEBRATE FOSSILS WITHIN TELM7

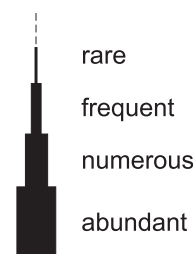

$\uparrow \leftarrow \quad$ concentration of invertebrate fossils $\downarrow \leftarrow \quad$ in Telm7

- $\quad$ pebbles and cobbles

$\because \because$ pebbles

- boulders

$\hat{n}$ shells

silt + sand

$\because \quad$ sand

bioturbated sandy mudstone

$\therefore$ sand-mud heterolith

$\therefore$ shell bed

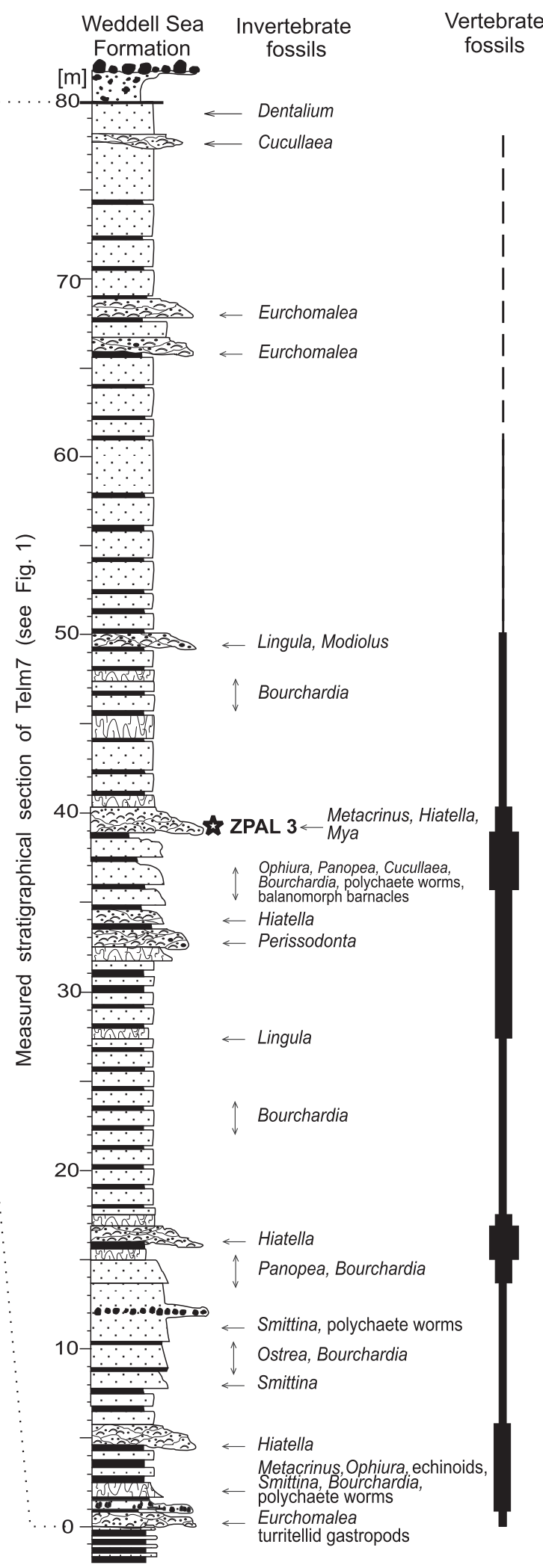

Fig. 2. Stratigraphic column of the Eocene La Meseta Formation on Seymour Island showing lithology and distribution of invertebrate and vertebrate fossils

Asterisk shows the stratigraphic level of the Mesetaichthys jerzmanskae n. gen. and n. sp.; modified from Myrcha et al. (2002: fig. 2) 


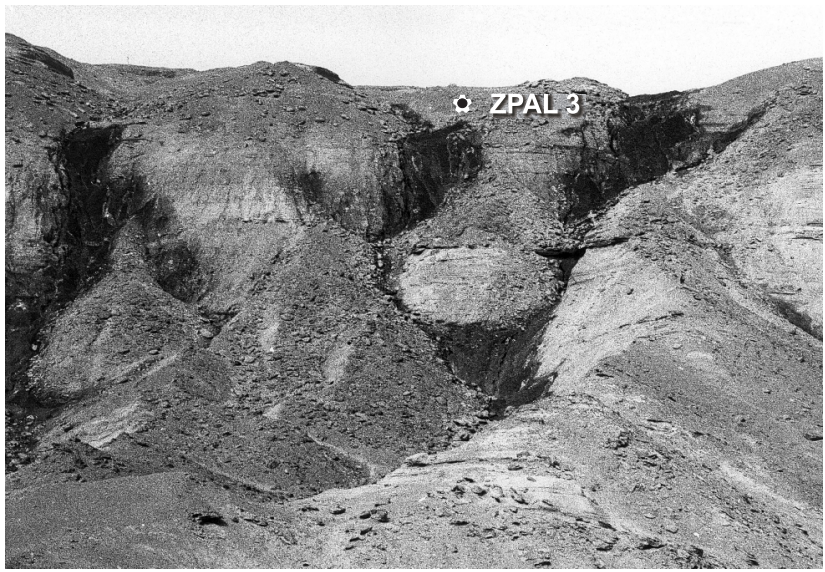

Fig. 3. View of the locality ZPAL 3 (asterisk), Telm7 (= Submeseta Allomember), Late Eocene

Photograph by A. Gaździcki, February 1992

The most valid referral of fossils to the notothenioid group is that by Balushkin (1994), who redescribed a part of a skull originally referred to Gadiformes by Eastman and Grande (1991), and included it in the primitive notothenioid, Eleginopsidae Gill (see Balushkin, 1992). It was the first determined fossil notothenioid, which Balushkin (1994) named Proeleginops grandeastmanorum. Eastman (2000) had been reluctant to accept the misidentification, but later he apparently accepted it (see Claeson et al., 2012). Arratia et al. (2004: p. 48) did not recognize Balushkin's revision. Proeleginops grandeastmanorum from locality RV 8200 in Telm5 (Case, 1992, 2006) which is Middle Eocene, ca. $45 \mathrm{Ma}$ in age (Case, 2006; Marenssi, 2006), is the oldest known notothenioid, some 10 m.y. older than the material described here.

Grande and Eastman (1986) in a review of all known Antarctic ichthyofaunas, discussed the likelihood that jaw fragments and vertebral centra from Upper Eocene of the La Meseta Fm. could be notothenioids - a possibility the authors naturally expected. They found no positive indications, that allowed "...a definitive diagnosis of this group..." although they did stress distinct similarities between some of the fossil vertebrae and those notothenioid Dissostichus. Grande and Eastman (1986: fig. 5) figured two premaxillary fragments and two dentary fragments from the Field Museum of Natural History, Chicago collection (FMNH), and determined the former as "...a gadiform type...", while the dentaries were described as "...indeterminate teleosts...". The latter, however, are now called "...definitively Merlucciidae..." by Claeson et al. (2012).

\section{RECENT NOTOTHENIOIDS}

Grande and Eastman (1986: p. 130) discussed the size of the Eocene fishes based upon the largest of the vertebrae in the Field Museum of Natural History, Chicago, which is "...generally similar to those of the Recent nototheniid Dissostichus mawsoni...", the Antarctic toothfish. This specimen is a caudal centrum $4.7 \mathrm{~cm}$ in diameter and $3.3 \mathrm{~cm}$ long. Grande and Eastman (1986) compared the size of this vertebrae to size of vertebrae of $D$. mawsoni and knowing the size of $D$. mawsoni they estimated that fossil fish had a standard length (SL) of ca. $2 \mathrm{~m}$. That was more than known at that time for $D$. mawsoni as the largest notothenioid in the Antarctic waters. This largest fish caught by Eastman and DeVries (1981) had a total length (TL) of $163 \mathrm{~cm}$. Today the more northern species $D$. eleginoides - which is found along the coast of southern South America from Peru to Uruguay and at many of the South Ocean islands - is known to reach a TL of $215 \mathrm{~cm}$ (Duhamel et al., 2005). This is the largest notothenioid, probably exceeding $100 \mathrm{~kg}$. Interestingly, this species has just once been caught off Greenland (Møller et al., 2003; see Fig. 15), and it is the only notothenioid ever found north of the Equator. Most of the notothenioids are much smaller reaching less than half a metre in length (see Fig. 14).

Osteological and phylogenetic studies of living notothenioids were presented by Balushkin (1984, 1992, 2000) and Voskoboinikova (1994, 1997, 1998), who also studied the ontogeny of the skeleton (Voskoboinikova and Bruce, 2001). Andersen (1984) studied the Nototheniidae and their classification and Iwami (1985) the Channichthyidae. However, published details concerning the skull anatomy, and teeth are difficult to find (only premaxillaries with teeth are shown by Balushkin, 1984). Gregory (1933) had published quite a few notothenioid skulls, including the primitive Eleginops that was referred by Balushkin (1992) to its own monotypic family. The molecular evidence for their relationship is discussed by Lecointre et al. (1997), Ritchie et al. (1997), Dettaï and Lecointre (2004) and Near (2004) using the fossil Proeleginops to calibrate the molecular clock for notothenioid origins.

\section{EARLY GADIFORMS}

Traditionally gadiforms are supposed to have originated in the north (Svetovidov, 1948). The oldest known gadiform and the only Paleocene skeleton assignable to this order is a complete fish from the Danian of West Greenland (Rosen and Patterson, 1969; Cohen, 1984). The earliest diversification of the gadiforms is recorded by skeletons from the earliest Eocene Fur Formation of Denmark (Bonde, 1987, 1997; Bonde et al., 2008, 2011). In the London Clay (late Early Eocene), there are two taxa of skeletal gadiforms, the merlucciid Rhinocephalus and the merlucciidlike teeth called Trichiurides (Casier, 1966; Rosen and Patterson, 1969); there are also five otolith species (Casier, 1966).

The gadiform otolith record is very different from that of the skeletons (Casier, 1966; Patterson, 1993). From the "Coral Limestone" of Faxe (Middle Danian, Early Paleocene, Denmark) a few juvenile indeterminate gadiforms are known (Schwarzhans, 2003). In the Danish Early Selandian (Middle Paleocene) as many as eight species of gadiforms were found: three macrourids and five species in four gadoid families. One Danish eulichthyid is known also from the Paleocene-Eocene of the United Kingdom and Belgium (Schwarzhans, 2003). Two macrourids and two gadoid species were found in Selandian, West Greenland (Schwarzhans, 2004).

In South Australia and New Zealand the earliest gadiform otoliths are from the Middle Paleocene (Selandian; a macrourid of the living genus Nezumia, Schwarzhans, 1985), and 3 species are known from Early Eocene (Schwarzhans, 1980). Bregmacerotids and primitive Euclichthys-like gadoids were found in Late Eocene. Macruronus otoliths are known from the Eocene of South Australia (Schwarzhans, 1981).

Kriwet and Hecht (2008) provided a review of early gadiforms and described a macrourid skull with otoliths in situ from La Meseta Fm (Telm3-5), an exceptional preservation. Rattail skeletons apart from that skull are unknown from the Paleocene and Eocene. Kriwet and Hecht (2008) accepted the determinations as gadiforms by Eastman and Grande (1991) and Jerzmańska and Świdnicki (1992) for jaws from the La Meseta Formation. Jerzmańska (in Doktor et al., 1996: figs. 11 and 12) has identified scales of gadiforms in the lower part of the La Meseta Fm. (Telm2, Early Eocene). Balushkin's argument (1994), that southern gadiforms are unlikely already in "Late Eocene", because they originated in the north thus is irrevelant. 

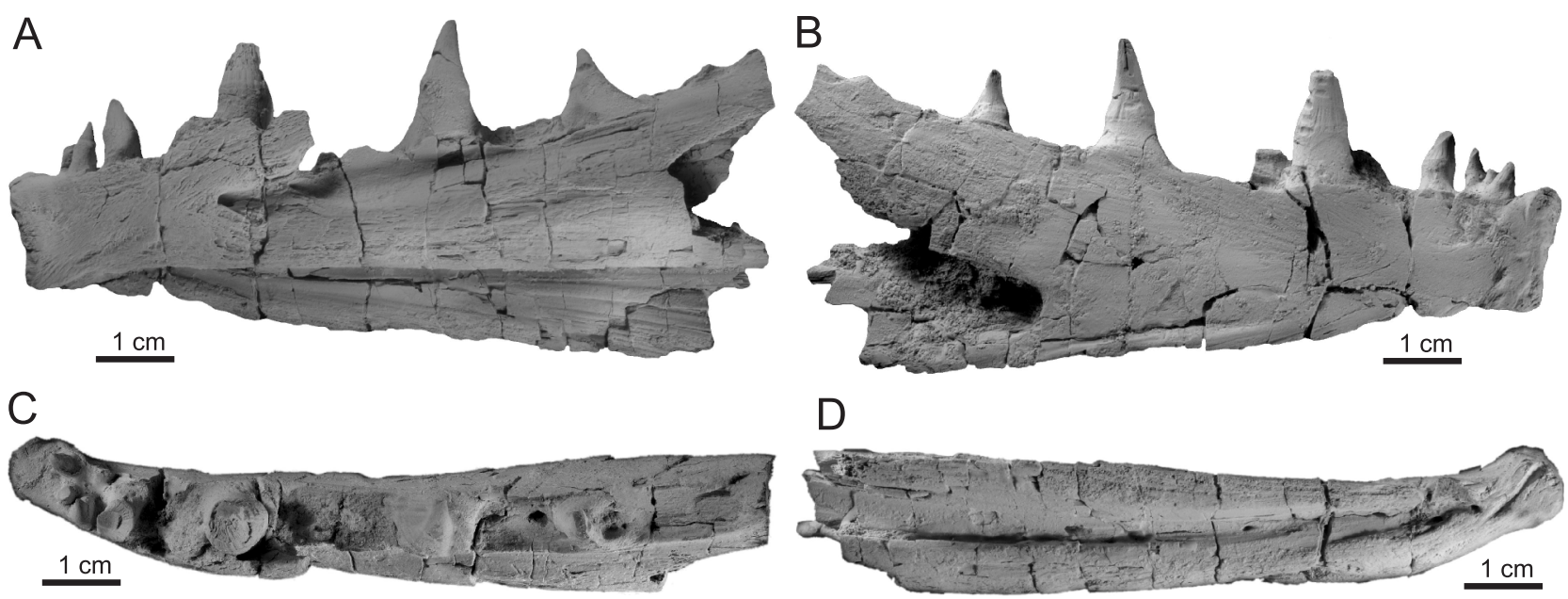

Fig. 4. Left dentary, ZPAL P.V./5, holotype of Mesetaichthys jerzmanskae n. gen. and n. sp., dusted with ammonium

A - lateral, B - medial, C - dorsal, D - ventral view; photographs by G. Dziewińska

\section{SYSTEMATIC PALAEONTOLOGY}

Order Perciformes

Suborder Notothenioidei

Family incertae sedis

Genus Mesetaichthys nov.

Ty p e species. - Mesetaichthys jerzmanskae sp. nov., only known species. La Meseta Formation, Late Eocene, Seymour Island, Antarctic Peninsula.

Derivation of $n$ a m e. - From the La Meseta Fm. and Greek ichthys means fish. The name was used informally by Jerzmańska and Świdnicki (1992: p. 246).

D i a g n o s i s. - As for the type and only species.

Stratigraphic and geographic range. - La Meseta Formation (Telm7), Late Eocene, Seymour Island, Antarctica.

Mesetaichthys jerzmanskae sp. nov.

(Figs. 4-11)

Hol o t y p e. - ZPAL P.V./5, a large fragmentary, but nearly complete dentary (Figs. 4, 5 and 6F).

P a r a t y p e s. - ZPAL P.V./1 and 2, proximal fragments of premaxillae (Fig. 7).

$\mathrm{M}$ a t e $\mathrm{r}$ i a l. - Referred materials are discussed below after the relevant descriptions.

Ty p e h o r i z o n. - Telm7 of the La Meseta Formation, Late Eocene.

T y p e I o c a l i t y. - ZPAL 3, Seymour Island, Antarctic Peninsula (Figs. 1 and 3 ).

Derivation of $n$ a m es. - Named in honour of the late Polish palaeoichthyologist Prof. Dr. Anna Jerzmańska (see Elżanowski, 2003).

D i a g n o s is. - The most characteristic feature is the dentition with strong, conical, slightly bent and pointed teeth standing on large bony pedicles (Figs. 4-8). Teeth mostly with an internal cavity with longitudinal ridges mirroring the external ridges and fissures in the "enameloid" at the base of the teeth proper. Teeth in one row, fang-like teeth in the premaxilla at the symphysis, but teeth diminishing backwards. Small teeth at the dentary symphysis, but very large "canines" at least in the mid-
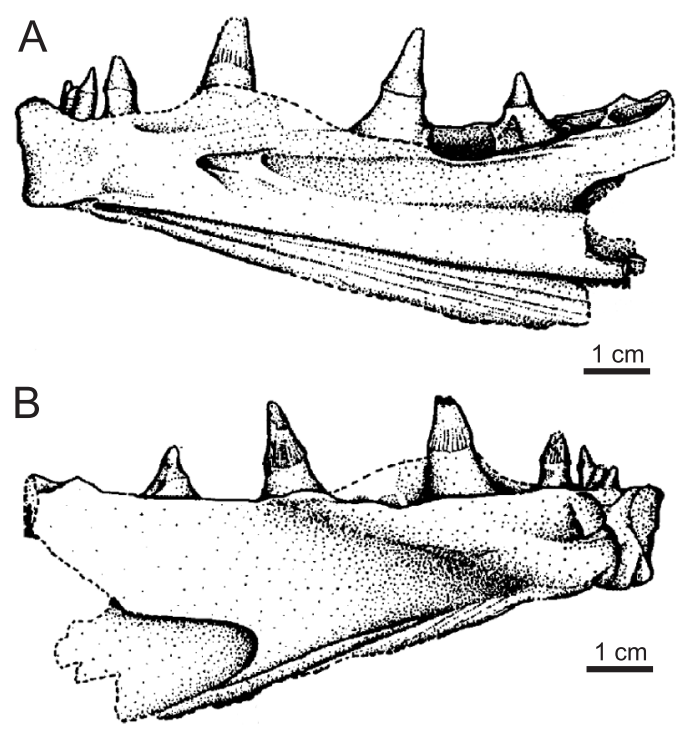

C

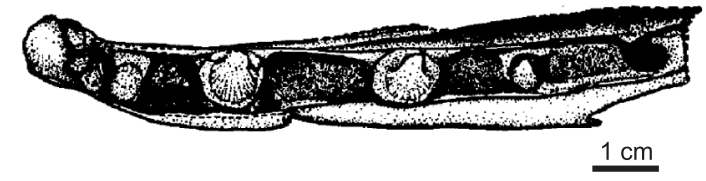

Fig. 5. Left dentary, ZPAL P.V./5, holotype of Mesetaichthys jerzmanskae n. gen. and $\mathrm{n}$. sp.

A - lateral, B - medial, C - dorsal view; drawings from Jerzmańska and Świnicki (1992)

dle of the dentary. Wide open groove for the mandibular sensory canal (Figs. 4-6F).

Description.

Holotype (The large dentary). The largest dentary fragment (ZPAL P.V./5; Figs. 4-6F) is about $10 \mathrm{~cm}$ long, and a few centimetre are missing from the posterior end of the dental edge and the ventral branch. The bone is about $1 \mathrm{~cm}$ wide at the dental edge where strong, conical teeth are fused to high, bony pedicles in a shallow groove (see Moy-Thomas, 1934; Fink, 
A

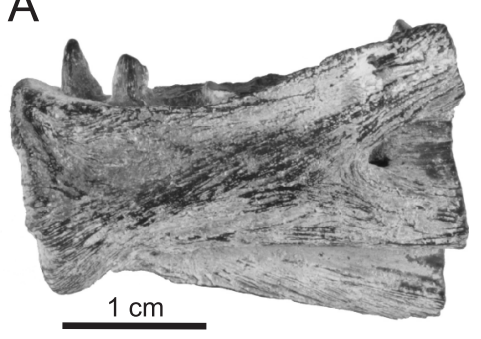

B

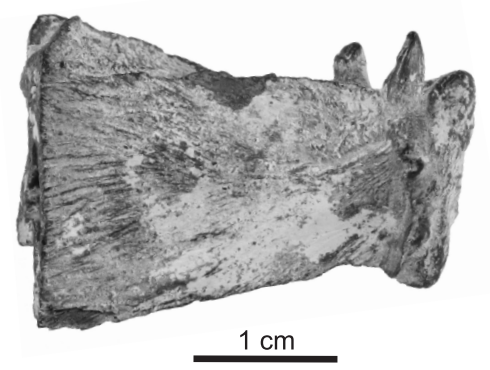

C

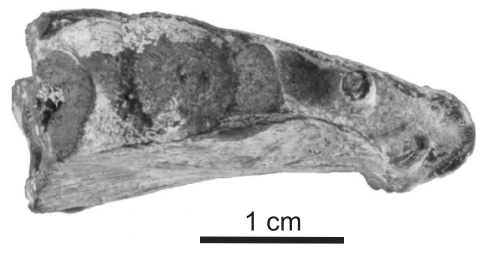

D

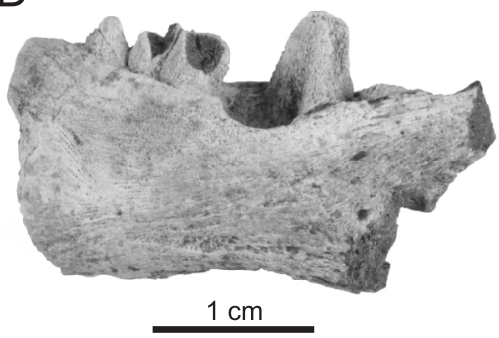

E

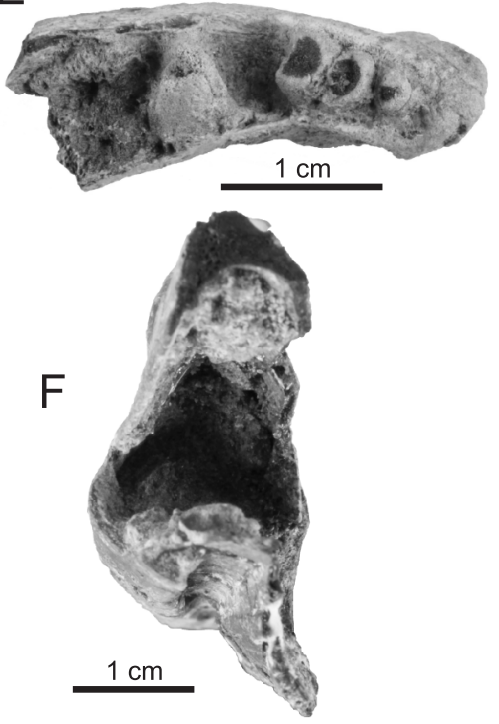

Fig. 6. Dentary fragments of Mesetaichthys jerzmanskae n. gen. and n. sp

A-E - dusted with ammonium; A-C - ZPAL P.V./9 in lateral, medial and dorsal views; D, E ZPAL P.V./11 in lateral and dorsal views; F - ZPAL P.V./5, the holotype in posterior view to show the large internal cavity and the open sensory canal; photographs by P.R. Møller

1981). Along the middle part of the lateral face of the bone a very strong, broad ridge is running smoothly into the strong symphyseal region, making the bone almost $2 \mathrm{~cm}$ wide below the last preserved tooth. Above this ridge along the laterodorsal margin there is a broad, distinct but rather shallow groove ending near the symphysis of the dentary, at two nerve foramina, below the strongest canine tooth. The first nerve foramen is ca. $1 \mathrm{~mm}$ in diameter, just posterior to and below the posterior face of this tooth, and the second is $2 \mathrm{~mm}$ in diameter, below the anterior margin of the tooth, it is running into a forwardly directed canal (the mental foramen). The posterior end of this groove is located at the lateral incision (Fig. 5A), the dorsal rim of which seems to be the natural thin edge of the bone (that tightly covered the missing dermarticular's anterior process), while the anterior and ventral edges of this incision are broken. The lateral lamina bending up at the pedicle below the large tooth is slightly more fragmented now, when comparing Figure 4A with Figure 5A (from Jerzmańska and Świdnicki, 1992), and likewise the interior dorsal flange of the dorsal branch has a damaged ventral edge slightly above the wide internal incision (see Figs. 4B and 5B). The ventral edge of the dentary (Fig. 4D) is very thin and almost straight and forms the internal wall of a deep, open groove for the mandibular sensory canal. Seen from behind (Fig. 6F) it is clear that the bone wall is quite thin around a wide mandibular (Meckelian) canal.

The internal face of the dentary is almost smooth and plane, only bending very slightly inwards at the ventral edge in the middle of the bone (Figs. 4B, D and 5B). Below the anterior small teeth there is a shallow depression, presumably for a muscle or ligament near the symphysis. The latter seems to have its ante- rior surface almost intact, about $15 \mathrm{~mm}$ high, and slightly bent inwards, indicating that the angle between the two dentaries must have been a very obtuse one. This indicates a very blunt and rounded snout without any fusion between the two bones, but rather a thin cartilage. The lateral surface of the bone shows a weak "bulge" or convexity below the interspace between teeth number four and five, and further anteriorly there is a slight depression below the three anterior teeth (Figs. $4 \mathrm{~A}$ and $5 \mathrm{~A}$ ).

The surface of this part and the strong lateral ridge has a fine and somewhat irregular ornament of thin grooves and ridges becoming a little coarser and straighter on the posterior part of the lateral ridge (Fig. 4A). This ornament, not shown in the drawing (Fig. 5A), is the reason for assuming that the bones described here, e.g. the premaxillaries and dermarticulars are probably from the same species. The ornament is not welldeveloped on the inside of the dentary (Fig. 4B), where there are only very faint and almost straight longitudinal grooves and ridges. The external face of the ventral lamina is ornamented by much stronger and more regular longitudinal grooves and ridges (Figs. 4A and $5 \mathrm{~A}$ ). The open groove for the mandibular sensory canal is quite smooth and rounded, it is deepest at the posterior margin of the dentary and seems to disappear into a foramen near the anterior margin of the dentary (Fig. 4D). The lateral wall of this groove is formed by the thick ridge. There are nerve foramina for the sensory "buds" in the canal at the top of the open groove (Fig. 4D), at least four can be seen (they are misleadingly called "...ventral sensory canal pores..." in Claeson et al., 2012: fig. 4).

The three posterior large and very robust teeth preserved are widely spaced. Between them are distinct depressions from teeth having fallen out. Probably two teeth are missing between the two anterior large teeth. Each tooth is conical, bent inwards and it is continuing the shape of its bony pedicle. The tooth's "shining" enamel-like cover has an ornament of fine and thin grooves at the base disappearing towards the tip of the tooth. These fine grooves were described by Jerzmańska and Świdnicki (1992: p. 245) as "...radiating from the tip to half or at least $1 / 3$ height of the tooth....", because apparently they did not recognize the base as a "bony pedicle" like described here (and by Moy-Thomas, 1934; Fink, 1981). There does seem to be a clearly marked distinction between these pedicles and the teeth proper with a difference of the surface structure, as is clearly indicated in drawings (Fig. 5) by Jerzmańska and Świdnicki (1992). There are four teeth also on pedicles being closely spaced near the symphysis with bases a little more oval. One is of "intermediate" size, the three anterior ones are small, their tips are also inclined inwards, and at least three of them show the same ornament at their bases. These basal pedicles all along are almost about the same height as the teeth proper.

The tips of most of the teeth are slightly damaged by post-mortem breaks exposing the thin outer and shiny layer being a little lighter coloured than the almost black interior, but none is broken at a level disposing the internal cavity. In the interspaces between the teeth the shallow groove shows irregular "spongy" 
bone structure. No traces of replacement teeth are seen. There might perhaps have been two teeth between the fourth symphyseal one and the anterior large tooth, which in that case would be position seventh. Marks on this tooth (Fig. 4B) are from sampling for isotope analysis (see Błażejowski et al., 2010).

This almost complete left dentary (Figs. 4-6F) is slightly bigger than that of the large Dissostichus ( $\sim 180 \mathrm{~cm}$ long, $\sim 70 \mathrm{~kg}$; Møller et al., 2003) from Greenland. Hence it indicates a fish of about 2 m length.

Other dentaries. Jerzmańska and Świdnicki (1992: fig. 4) described a small fragment (ZPAL P.V./6) from the posterior end of the dental ridge with 3-4 closely set and diminishing teeth of which the larger one clearly has a bony pedicle (their fig. 4). This is accepted here as probably representing Mesetaichthys jerzmanskae.

There are two other well-preserved dentaries (ZPAL P.V./9 and 11; Fig. 6A-E) showing the symphyseal region. Both are from the left side and are $30 \mathrm{~mm}$ long and very close to $15 \mathrm{~mm}$ high at the symphysis as ZPAL P.V./5, but they are slightly shallower than the latter posteriorly to the symphysis. ZPAL P.V./9 (Fig. 6A-C) is the better preserved ending at a clear and nearly vertical cut through the bony base of a tooth corresponding to the 6th or 7th position in ZPAL P.V./5, which represents the anterior large tooth.

Specimen ZPAL P.V./11 although more broken (Fig. 6D, E), represents anterior part of dentary and is lacking part of the medial surface. It has seven tooth-positions preserved, the last irregularly broken bony pedicle corresponding to the anterior big one of specimen ZPAL P.V./5 (Fig. 4). Its small anterior tooth is missing from its position very close to the medial face directly posterior to the symphysis, but teeth numbers two to four are preserved as bony pedicles cut near tops of pendicles, and teeth two and four are showing traces of the internal cavities (Fig. 6E). The fifth tooth has left a deep, round groove, while the rather strong sixth is cut almost vertically through the middle of its high bony pedicle and its internal cavity. The latter, as well as the base of the cavity of seventh tooth, shows weak traces of internal, vertical ridges and furrows, and the same is the case in the basal cavity of the bony pedicle of one of the posterior preserved tooth in specimen ZPAL P.V./9. The latter is lacking the small second tooth, and all teeth between the third and posterior preserved tooth, all leaving deeper or shallower pits, which show no traces of the interior cavities (Fig. 6C). Teeth number one and three clearly show fine ridges and furrows at the base of the tooth proper, and when approaching the large posterior tooth the lateral edge of the dental groove is ascending like in specimen ZPAL P.V./5. First tooth is the only tooth of $M$. jerzmanskae preserving the almost complete tip, clearly without a sharp "cap".

Specimen ZPAL P.V./9 exhibits the anterior end of the large mandibular (Meckelian) canal, the anterior $22 \mathrm{~mm}$ of the smooth groove for the mandibular sensory canal, and the large, lateral foramen below the large posterior tooth. The bony surface shows the same ornamentation as specimen ZPAL P.V./5, although slightly stronger longitudinal ridges mark the posterior part of the medial surface of the fragment (Fig. 6A).

There is no reason to doubt that these two dentary fragments represent $M$. jerzmanskae. Very importantly, they show the internal cavities of the bony pedicles with their faint ridges and furrows. The remaining dentaries, specimens ZPAL P.V./6-16 also seem to belong to this species, but are more fragmentary.

Premaxillae. The better preserved premaxillae are specimens ZPAL P.V./1, 2, described and figured by Jerzmańska and Świdnicki (1992: fig. 1; here Fig. 7), both from the left side with the proximal and articular head of the bone, both here selected as paratypes. We feature in some detail specimen ZPAL P.V./1 with two anterior "fangs" being preserved (Fig. 7A, C, $E-G)$. The short rounded ascending process is well-preserved and shows an external ornament similar to that of the lateral face of the dentaries. This rather thin and flat process has an internal face (Fig. 7F) with a coarse ornament of straight, thin
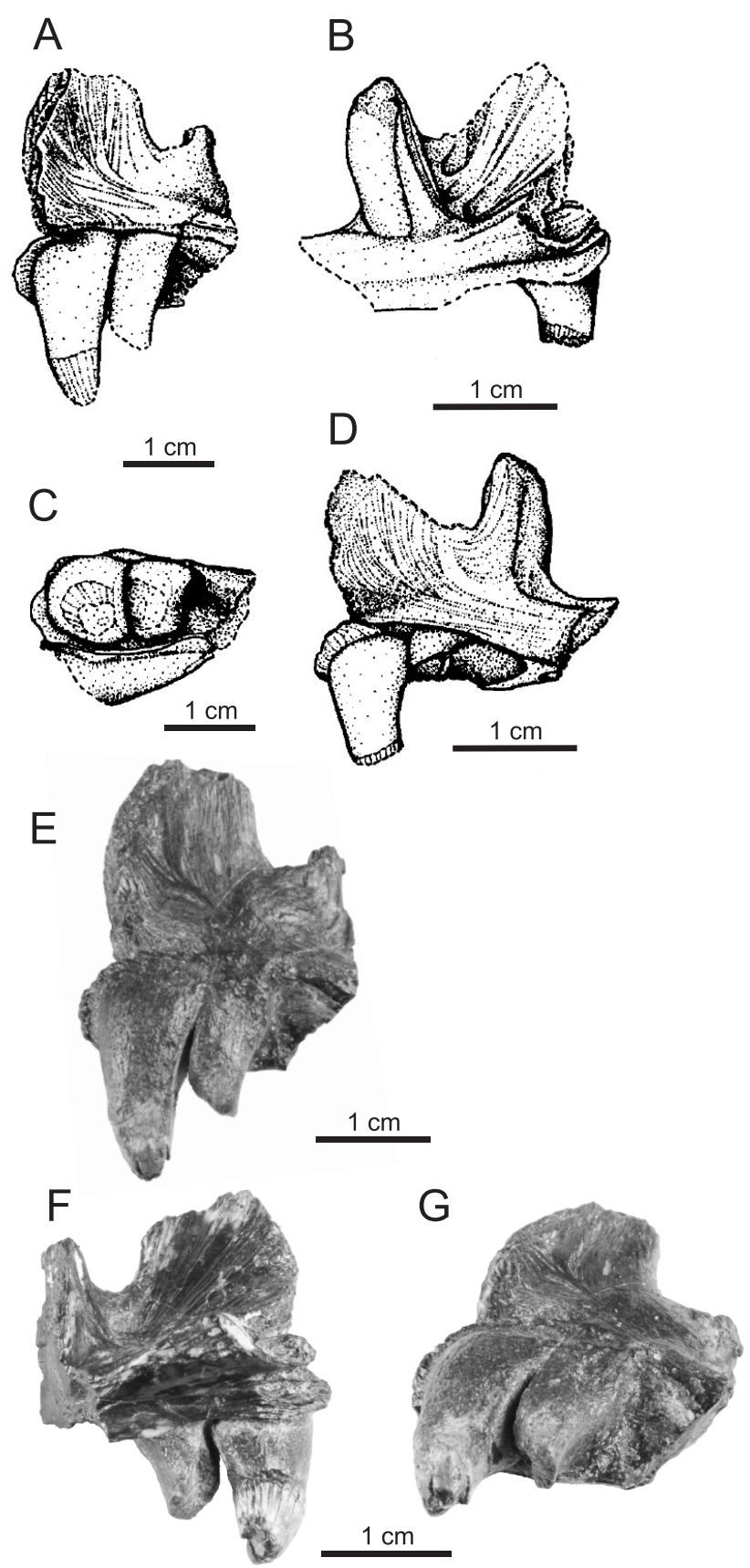

Fig. 7. Symphyseal regions of premaxillaries of Mesetaichthys jerzmanskae n. gen. and n. sp.

A, C - ZPAL P.V./1 in left lateral and ventral views; B, D - ZPAL P.V./2 in medial and left lateral views; E-G - ZPAL P.V./1 in left lateral, medial and latero-ventral views; A-D - drawings from Jerzmańska and Świdnicki (1992); photographs by P.R. Møller 
ridges radiating out from the medial cavity between the ascending and articular processes. This medial cavity also has 2-3 nerve foramina "radiating" in the same direction as ridges of the ascending process (also seen in ZPAL P.V./2; Fig. 7B). The ascending process is about 7-8 $\mathrm{mm}$ thick at its basis, but very thin, almost sharp at the dorsal edge. Only the anterior part of the strong articular process is preserved (Fig. 7A, E, F). Specimen ZPAL P.V./2 shows the entire articular process which is about the same size as the ascending process, but stronger and slightly more narrow (Fig. 7B, D). It shows a lateral, vertical ridge in the middle of the process, presumably indicating how far forward the articular head of the maxilla would have covered the premaxilla. Only a small part of the dentigerous branch of the bone is preserved in ZPAL P.V./2 corresponding roughly to four tooth positions but only the bony pedicle of the large anterior "fang" is preserved. In ZPAL P.V./1 the dentigerous branch of the bone is corresponding to three anterior teeth (Fig. 7E-G). Specimen ZPAL P.V./1 has the two anterior teeth and pedicles partly preserved, the second one broken in the pedicle showing traces of the internal cavity. The anterior tooth is a very strong, conical and inwardly bent "fang" with the tip broken off to disclose a large internal cavity (Fig. 7F). Including nearly $15 \mathrm{~mm}$ as a bony pedicle, the tooth itself with strong, closely set ridges at the base is about $7 \mathrm{~mm}$ high as preserved, and restored with the point would have been at least $2.5 \mathrm{~cm}$ high. The width of its base is about $8 \mathrm{~mm}$, and the "enameloid" of the tooth has a light brown colour, as opposed to the much darker bone and the dentine interior of the tooth which is nearly black (Fig. 7F). The posterior wall towards the next tooth is slightly concave giving it in fact a sub-triangular base (Fig. 7C, E, G). The second tooth is broken at the top of the bony pedicle and as preserved is ca. $12 \mathrm{~mm}$ high, also bent inwards, and with the internal cavity mostly filled by spongy bone. Its base is $6 \mathrm{~mm}$ wide, but slightly wider perpendicular to the jaw giving it an "ovaloid" shape, but with a nearly flat front wall. The posterior wall is a little concave, apparently worn by the next and now missing tooth, which has left only a shallow cavity (Fig. 7C, G). So the teeth are very closely set, decreasing in size backwards, and ornamented like the dentary teeth. They must have formed an "overhanging" upper jaw opposing the small teeth at the symphysis of the dentary (Figs. 4 and 5). Specimen ZPAL P.V./3 may also be from this species. Grande and Eastman (1986) figured similar fragments mostly with missing teeth.

Specimen ZPAL P.V./4 is a slim distal part of a premaxilla with three teeth and intervening shallow grooves of four missing ones (Fig. 8; assuming that this fish is much too advanced to have a toothed maxilla). Only the bony pedicles are preserved of the teeth, and they have dark spongy bone in the interior and no cavity. On its dorsal margin is a shallow groove which may have accommodated the ventral edge of the maxilla. We assume that all premaxillaries belong to M. jerzmanskae.

Jaw articulation. Several strong dermarticulars were found, and the two best preserved ones (ZPAL P.V./17, 18) are figured by Jerzmańska and Świdnicki (1992). The anatomically more complete fragment (ZPAL P.V./18; Fig. 9C-F) is from the right side, ca. $3.5 \mathrm{~cm}$ long showing the articular surface, which extends much further down the medial face than on the lateral face. The length of the articular or glenoid cavity is ca. $15 \mathrm{~mm}$ measured across to the tip of the post-articular process. The strong post-articular process is ca. $13 \mathrm{~mm}$ high, and the ventral edge is incomplete where the retroarticular is missing. Below the articular surface on the lateral side is a wide open groove for the mandibular sensory canal which has a small ridge overhanging it from the strong lateral ridge of the dermal component (Fig. 9C, D). The articular surface continues forward by the dorsal ascending part of the bone at an angle of about $30^{\circ}$ with re-

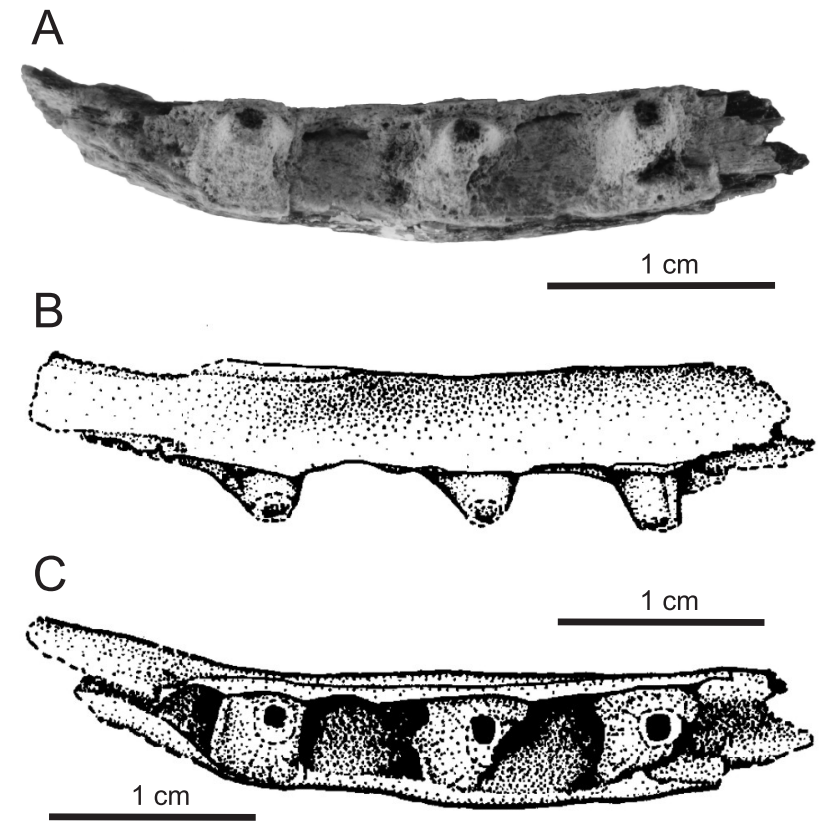

Fig. 8. Supposed more distal right premaxillary fragment of Mesetaichthys jerzmanskae n. gen. and n. sp. (ZPAL P.V./4)

\section{A - ventral view; B, C - drawings from Jerzmańska and Świdnicki (1992) in medial and ventral views; photograph by P.R. Møller}

inforcement along the dorsal edge. On the inside there is a small cavity up behind the down-turned articular surface, and there are two narrow cavities anterior to the articular surface. There is a large cavity in the bone between the strong lateral ridge (lateral wall) and the medial wall (Fig. 9E, F).

Specimen ZPAL P.V./17 (Fig. 9A, B) from the left side is from a much bigger animal and is $4 \mathrm{~cm}$ long and almost $2 \mathrm{~cm}$ measuring across the articular surface, and part of the bone is broken off anteriorly. Its post-articular process is $25 \mathrm{~mm}$ high, and a tiny bit may be missing at the sharp ventral edge. Rough and pitted lateral surface shows where the missing retroarticular was sutured (Fig. 9A). The ventral part of the bone below the wide open groove for the sensory canal is much higher than preserved in specimen ZPAL P.V./18, and the ventral edge seems broken and incomplete. The same three cavities or pockets are seen behind and in front of the smooth medial "tongue" of the articular surface (Fig. 9B). The dorsal edge slanting upwards is not preserved. The lateral surface of the bones (Fig. 9A, C) has a structure reminiscent of that of the dentaries (Figs. 4 and 6). Both bones are very incomplete in front with the presumably long and pointed process for articulation with the dentary broken off. We assume that the described (ZPAL P.V./17, 18) and the remaining five dermarticulars (ZPAL P.V./19, 23) belong to M. jerzmanskae.

Basioccipital. This single bone (ZPAL P.V./24; Fig. 10) is $26 \mathrm{~mm}$ wide and $21 \mathrm{~mm}$ high at the concave articular facet, and it is $45 \mathrm{~mm}$ long at the midline, but broken at the front margin. There are two deep excavations in the ventral surface (Fig. 10F) for thick posterior prongs of the parasphenoid with a strong ridge and in front a nearly $1 \mathrm{~cm}$ high, vertical wall between them (Fig. 10A). The dorsal interior surface has a blunt ridge in the midline on top of the mentioned wall, and the bone has a flat sloping surface dipping about $20^{\circ}$ towards the lateral edge (Fig. 10A, D). The latter is broken at both sides (Fig. 10A, $B)$, but rather thin, and the bone may not have been much wider than about $3 \mathrm{~cm}$. Comparing with many skulls figured by 
A
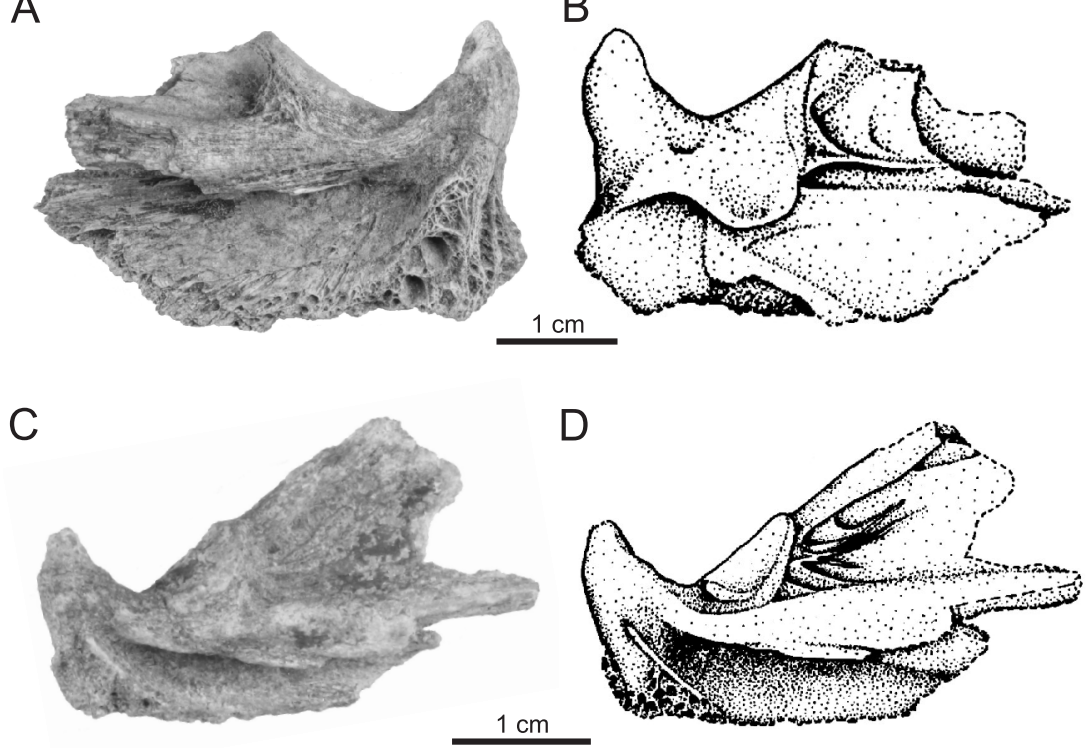

E

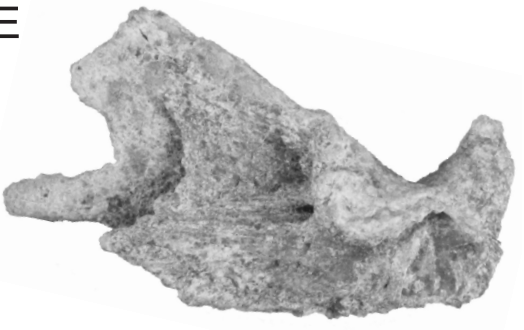

$\mathrm{F}$

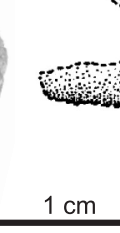

Fig. 9. Dermarticulars of Mesetaichthys jerzmanskae n. gen. and n. sp.

A, B - ZPAL P.V./17, left side, lateral and medial views; C-F - ZPAL P.V./18, right side in lateral $(C, D)$ and medial $(E, F)$ views; photographs (A, C, E) by P.R. Møller; drawings (B, D, F) from Jerzmańska and Swidnicki (1992)

It is possible that the basioccipital (ZPAL P.V./24) belongs to $M$. jerzmanskae, but this is uncertain.

Vertebrae. The described collection comprises 21 vertebrae with short centra (ZPAL P.V./25-45; Jerzmańska and Świdnicki, 1992). The centra were measured by Jerzmańska and Świdnicki (1992: table 2). Some have quite strong parapophyses (Fig. 11A-D), as also in some nothenioids and many gadoids. Many of the centra show several lateral bony lamellae (Fig. 11B, F; like their figs. 7 and 8 of ZPAL P.V./31, 32), a feature found in both some notothenioids (Fig. 12E) and some gadiforms.

Specimens (ZPAL P.V./29; Fig. 12C, D and ZPAL P.V./30) having large, lateral cavities for ribs, could be from different species than the others. They are unlikely to be notothenioids, as these have weak or missing ribs (Grande and Eastman, 1986: p. 128). Such centra were mentioned by Jerzmańska (1988: p. 425) and special similarity was found with the merlucciid Macruronus. Some of the centra (ZPAL P.V./34-42) have been determined as something more specific by Jerzmańska (dated 1992 on the labels), namely "Macruronus" (see Fig. 12A, B). Jerzmańska (1988: figs. 7, 8) illustrated very similar centra and described them as gadiforms.

Gadiform vertebrae are not usually short, but rather equally long and high. Several of the centra are from

Balushkin (1984) the lateral wall may have been rather low, and therefore not much appears to be missing. Grande and Eastman (1986) unfortunately did not describe the basioccipital of the fossil skull.

Just in front of the dorsal edge of the facet for articulation (Fig. 10C, E) is a sub-horizontal irregular sutural surface for the exoccipitals (Fig. 10D), indicating that these were in a posterior position at the level with the facet, and they met each other above the facet. This sutural surface also has paired and rather deep, blunt cavities which are $4 \mathrm{~mm}$ long and $3 \mathrm{~mm}$ wide, and in front and below from those there are two much broader cavities $1 \mathrm{~cm}$ across still filled with matrix, and forming the posterior wall of the ventral part of the brain cavity (Fig. 10A, D).

This arrangement does not look at all like that in gadiforms, were the exoccipital articulations are placed much further anteriorly, and those two bones do not meet in the midline (see Gregory, 1933; Svetovidov, 1948; Mujib, 1967; Rosen and Patterson, 1969). This criticism was made by Balushkin (1994) concerning the exoccipital-basioccipital positions in the skull originally described by Eastman and Grande (1991) as a "gadiform", but shown by Balushkin (1994) to be a notothenioid. It is likely that in a fish of this size, indicated by the isolated basioccipital, the exoccipitals and basioccipital would be fused together in a gadiform, while notothenioids tend to ossify very late (Voskoboinikova, 1994). quite large fishes, probably over one metre long. The vertebrae cannot with certainty be referred to $M$. jerzmanskae, but large size might indicate, that some of them are quite likely from this taxon.

O c c u r re n c e. - La Meseta Formation (Telm7), Late Eocene.

\section{COMPARISONS}

Grande and Eastman (1986) discussed the possibility that upper and lower jaw fragments they illustrated from the La Meseta Fm. were notothenioids, and they decided that the premaxillaries were probably from gadiforms, and the dentaries were indeterminate like the vertebrae. This opinion was changed concerning dentaries (Claeson et al., 2012) when describing a poorly preserved bone with fragmentary dentition, and the determination became much more precise as "merlucciids", following Jerzmańska and Świdnicki (1992). Clearly these jaw fragments are of the same sort as the more well-preserved ones described here, just from much smaller fishes.

The jaw fragments described by Jerzmańska and Świdnicki (1992) were only compared with gadoid fishes (8 spp. from 3-4 families). Seven features were used (two from premaxillae, 

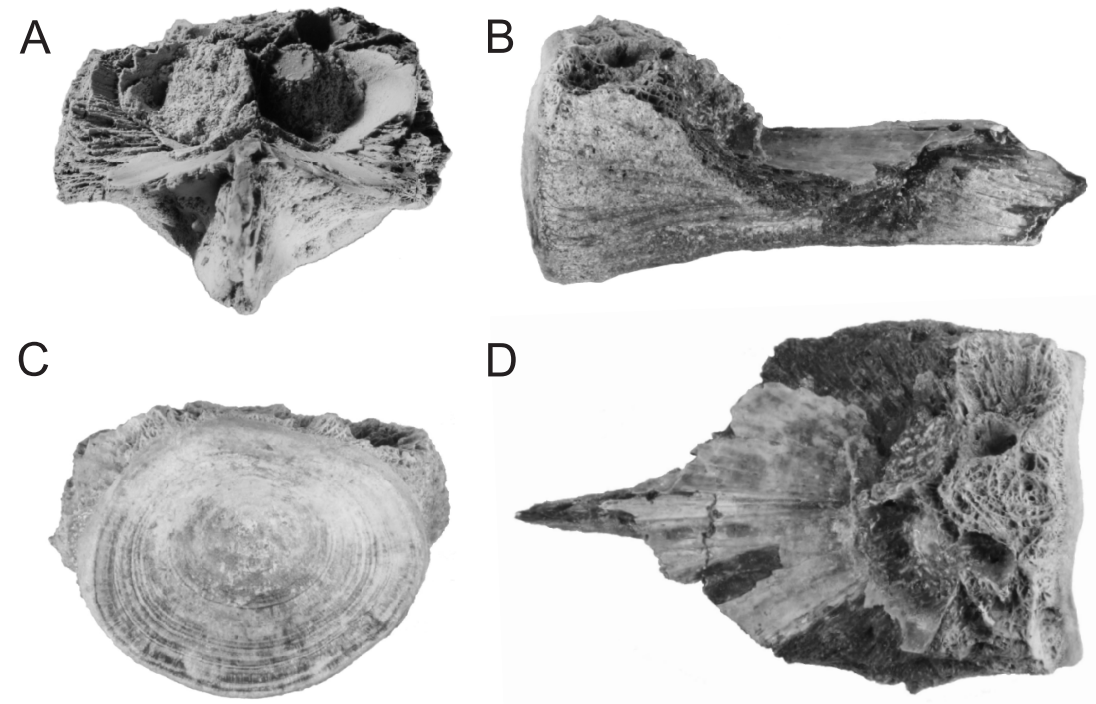

$\mathrm{E}$

$\mathrm{F}$
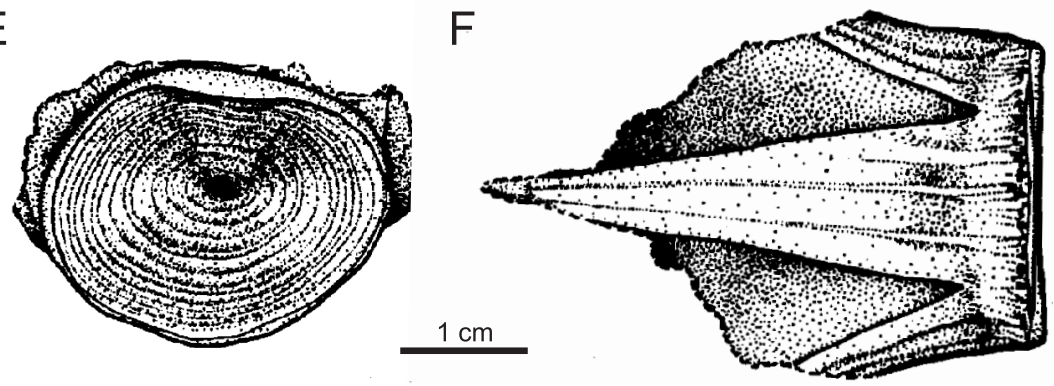

Fig. 10. Basioccipital, supposedly from Mesetaichthys jerzmanskae n. gen. and n. sp. (ZPAL P.V./24)

\begin{abstract}
A - anterior, B - right lateral, C - posterior, D - dorsal, E - posterior, F - ventral view; photograph by M. Dziewiński, dusted with ammonium (A) and by P.R. Møller (B-D); drawings (E-F) from Jerzmańska and Świdnicki (1992)
\end{abstract}

three from dentaries and two from dermarticulars), and of these traits six were similar in Merluccius, while the rest (including the merlucciid Melanonus) only matched one or two characters. The conclusion was "gadiform" relationship for the fossils, although the match with the majority of the material was poor, and they indicated (Jerzmańska and Świdnicki, 1992: p. 248) that the dentitions are quite different. Claeson et al. (2012) took the determination a step further as "merlucciid" (although very little similarity with Melanonus), and they tried to invoke also the dentition as an argument. We find especially the latter entirely unconvincing, because Merluccius has very different dentition.

Notothenioids like Chaenocephalus (Fig. 14E) have premaxillary ascending and articular processes not unlike those of the fossils which like in most gadiforms are low and rounded, not with the ascending process higher and slimmer than the articular process, as is the case in by far most perciforms and also nototheniids like Dissostichus (Fig. 15D; see also Balushkin, 1984: fig. 15; Gregory, 1933). The "trend of development" in notothenioids is the reduction in relative size of the ascending process of premaxilla (Balushkin and Voskoboinikova, 1995).

We recognize that the fossil dentaries indicate a broad and rounded snout. The dentition is very unlike that of gadiforms, as none of those have "fangs" at the front of the premaxillary, neither gadiforms have small teeth at the dentary symphysis.
The dentition of the gadoid Merluccius (see Figs. 13 and $14 \mathrm{C}, \mathrm{D})$ with sharp, pointed, rather strong teeth in two rows is not similar to the dentition of Mesetaichthys: the teeth are slim and smooth (also inside) and there are no "fangs", they are about the same size all along the jaws. They also have a small sharp "cap" (Fig. 14G, H) on each tooth, which admittedly could have been broken off in the Mesetaichthys jaws showing only one of the small symphyseal teeth with the point preserved. The only similarity between the dentition of Mesetaichthys and Merluccius is that the teeth are bent inwards (Figs. 5C, 7F and 13) and some are hollow (Fig. 14H).

One feature which could be a gadiform one is the large, open groove for the mandibular sensory canal (Figs. 4A, D; 5A and 6F), as also stressed by Claeson et al. (2012). Most gadiforms have such open grooves (Fig. 14D), while this is very rare in perciforms (exceptions e.g., percoids-like Howellidae; see Prokofiev, 2007), and we have seen none in notothenioids, neither in our few skeletons (Fig. 14) nor our X-rays (Fig. 15). The open sensory mandibular canals are unknown in notothenioids (according to personal information from Dr. Balushkin, April 2012; see also Claeson et al., 2012). We are, however, struck by some detailed similarity in the dentition of these fossils and living notothenioids, specifically that of the huge Dissostichus (Fig. 15). Mesetaichthys has two striking similari- 

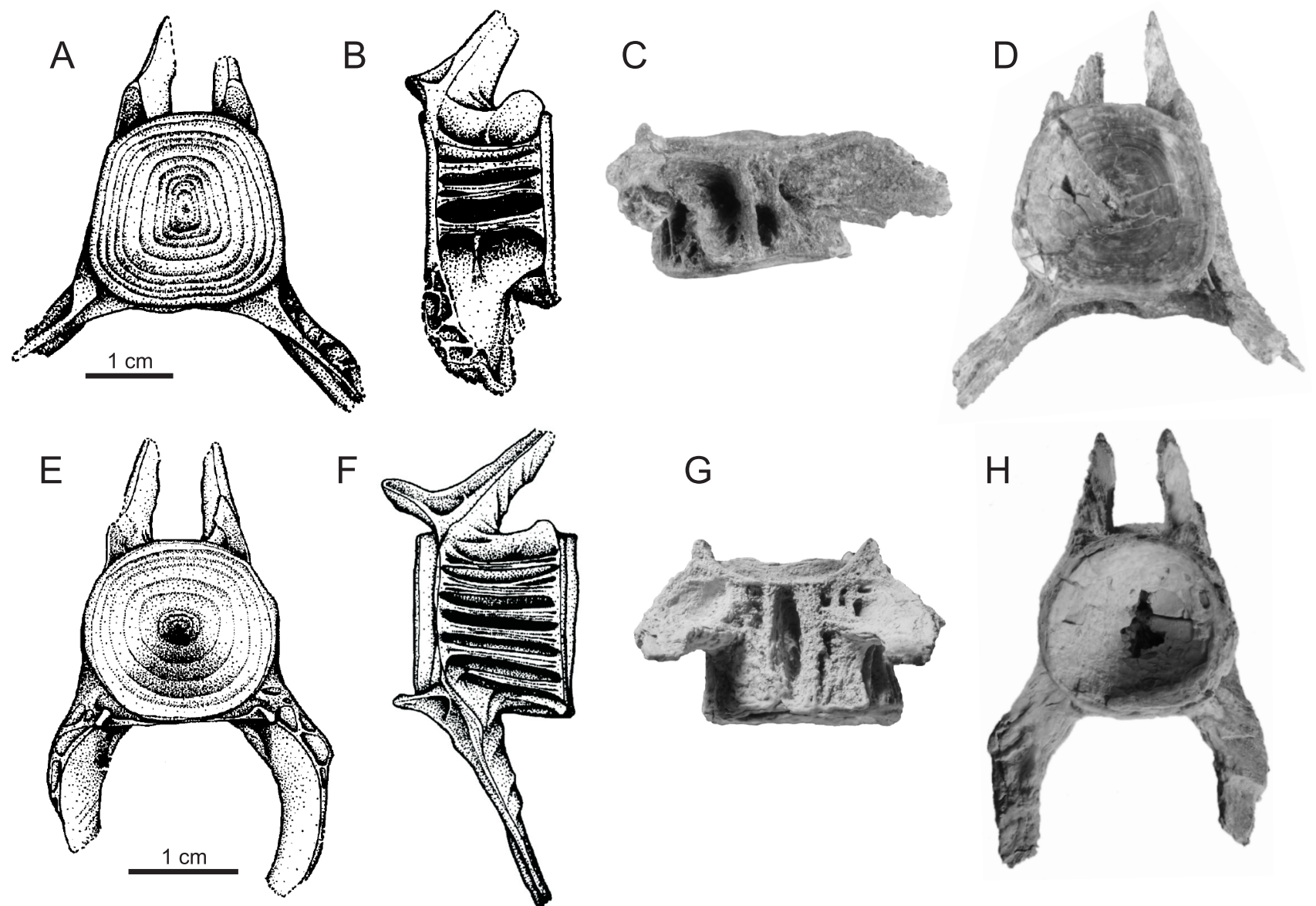

Fig. 11. Vertebrae of ?Mesetaichthys jerzmanskae n. gen. and $\mathrm{n}$. sp.

A-D - ZPAL P.V./31 in anterior, right lateral, ventral and posterior views; E-H - ZPAL P.V./32 in anterior, right lateral, ventral and posterior views; photographs by P.R. Møller (C-D) and by M. Dziewiński (G-H, ammonium dusted); drawings (A, B, E, F) from Jerzmańska and Świdnicki (1992)
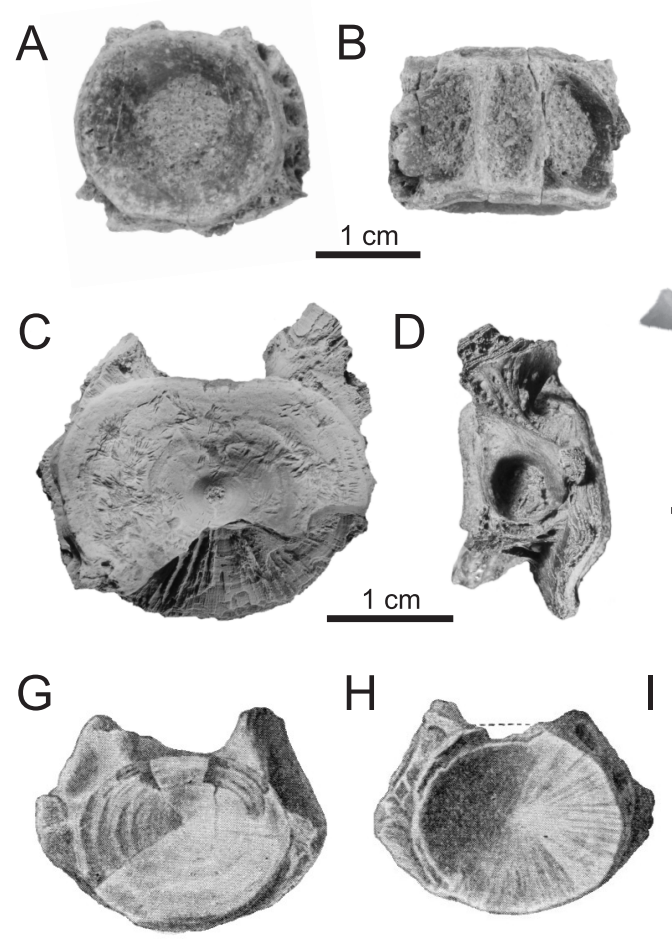

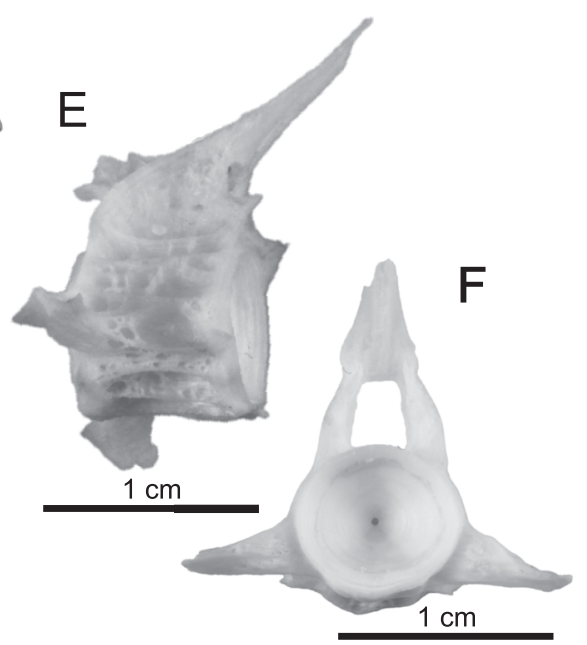

$\mathrm{J}$

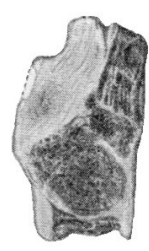

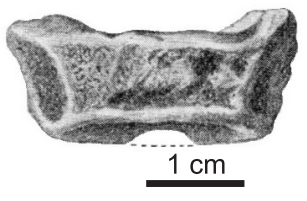

Fig. 12. Vertebrae

A, B - abdominal of so-called "Macruronus", ZPAL P.V./35, ?anterior and ventral views; C, D - ZPAL P.V./29, anterior abdominal with large, deep rib cavity from Teleostei indet; $\mathbf{E}, \mathbf{F}-$ abdominal vertebra of recent Notothenia; G-J - Woodward's so-called Notothenia sp., foremost vertebral centrum in anterior, posterior, left lateral and ventral views (from Woodward, 1908); photographs by P.R. Møller (A, B) and by M. Dziewiński (C, D dusted with ammonium) 


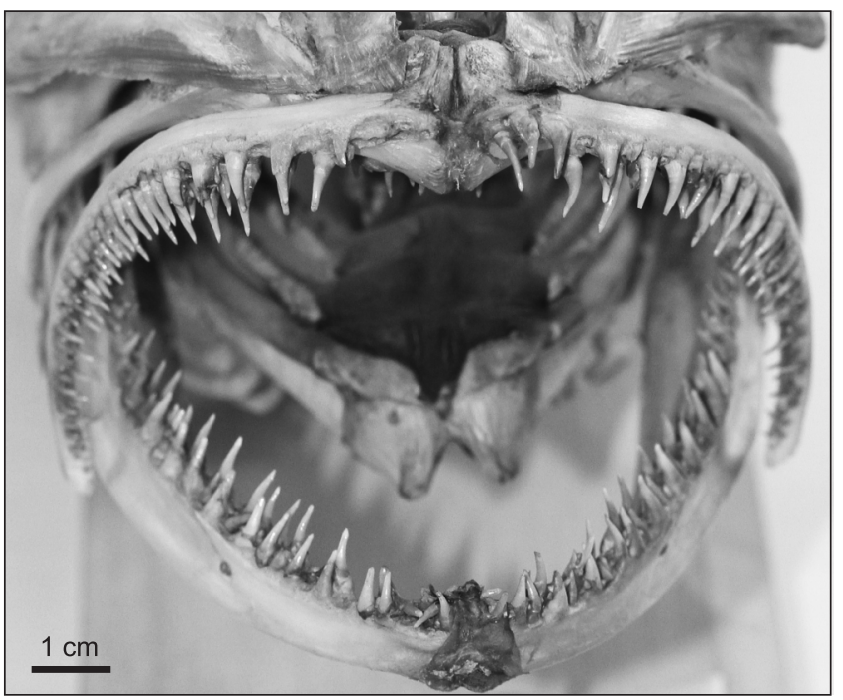

Fig. 13. Merluccius merluccius (Jrn. 215, dry skeleton), gape showing the strong, slim, pointed teeth with glittering acrodin caps in two rows in the jaws (and strong vomerine teeth are barely visible)

\section{Photograph by P.R. Møller}

ties to this living rather primitive nototheniid in the pattern of the dentition and in the detailed structure of the teeth. Dissostichus also has fanglike teeth at the premaxillary symphysis, very small teeth at the dentary symphysis, fanglike teeth in the middle of dentary, and the single teeth furrowed on the base at the pedicle, and the cavity is ridged to correspond to the external striation.

There is only little overlap in basioccipital (Fig. 10) and the skull roof and neurocranium of the notothenioid (Middle Eocene) from the La Meseta Formation, Proeleginops grandeastmanorum Balushkin (1994), but, in fact, the latter has a basioccipital which is not really like a gadiform one. Therefore we do not know if the two taxa could be synonymous, and in that case the skull roof only a few cm long would clearly be from a juvenile specimen.

Isolated centra from Seymour Island were described by Woodward (1908: fig. 5) and referred to Notothenia (Fig. $12 \mathrm{G}-\mathrm{J}$ ). It seems certain that there is more than one type of vertebrae previously referred to "Mesetaichthys" and accordingly much doubt about which centra may belong to the skull bones of $M$. jerzmanskae, and this raises doubt also about the referral of the basioccipital. It seems quite likely that some centra are notothenioid, and that the larger ones could belong to $M$. jerzmanskae.

\section{NOTOTHENIOID EVOLUTION AND DETERIORATION OF CLIMATE}

The oldest representatives of notothenioids, $P$. grandeeastmanorum Balushkin, 1994, (Telm5) and M. jerzmanskae n. gen. and n. sp. (Telm7) are recognized in the La Meseta Formation. In the formation a gradual deterioration of climate is recorded, with the evidence of decreasing temperatures through the later Eocene culminating with the first Antarctic glaciations at the Eocene-Oligocene boundary (Gaździcki et al., 1992; Dingle et al., 1998; Birkenmajer et al., 2005; Ivany et al., 2006, 2008; Tatur et al., 2006; Francis et al., 2009; see also Cantrill and Poole, 2012). Most possibly, the origin of

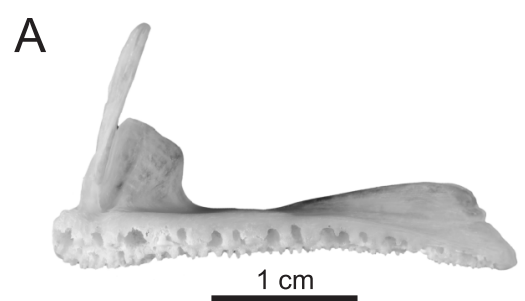

B

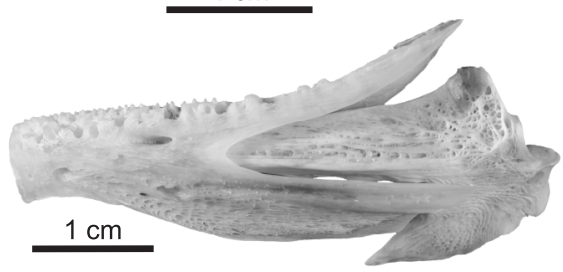

C

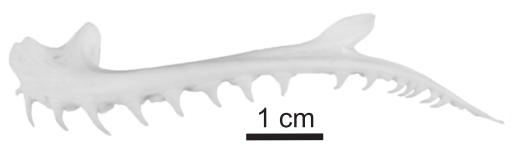

D

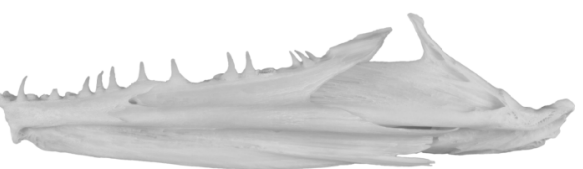

E

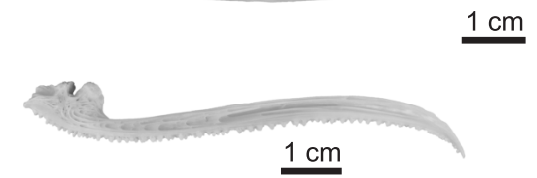

F

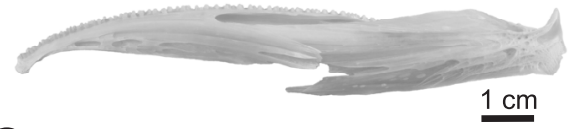

G

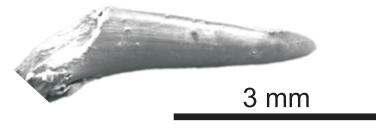

$H$

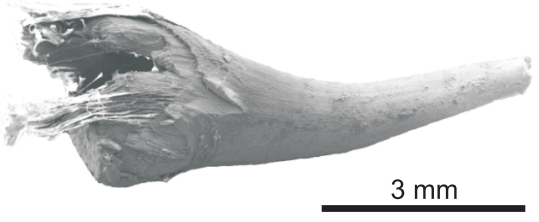

Fig. 14. Dry bones of recent fishes

A, B - Notothenia microlepidota (ZMUC uncat., 7495 dry skeleton), left lower jaw and right premaxilla, both in lateral view; C, D - Merluccius merluccius (fish shop, Copenhagen, ZMUC uncat.), views as above; E, F Chaenocephalus aceratus (ZMUC uncat., 7741 - dry skeleton), left lower jaw and premaxilla; G, H - MerIuccius merluccius tooth, SEM photo showing smooth pulp cavity, cutting edge, also on the distinct cap/tip (uncat. specimen); photographs by P.R. Møller (A-F) and $\mathrm{C}$. Bonde $(\mathrm{G}-\mathrm{H})$

the notothenioids is linked to this climatic event, as was hypothesized already by Regan (1914) and mentioned by Grande and Eastman (1986: p. 134).

The earliest diversification of notothenioids with anti-freeze liquids in the blood (AFGP of Near, 2004) according to the molecular biologists took place in the earliest Miocene ( 24 Ma; 

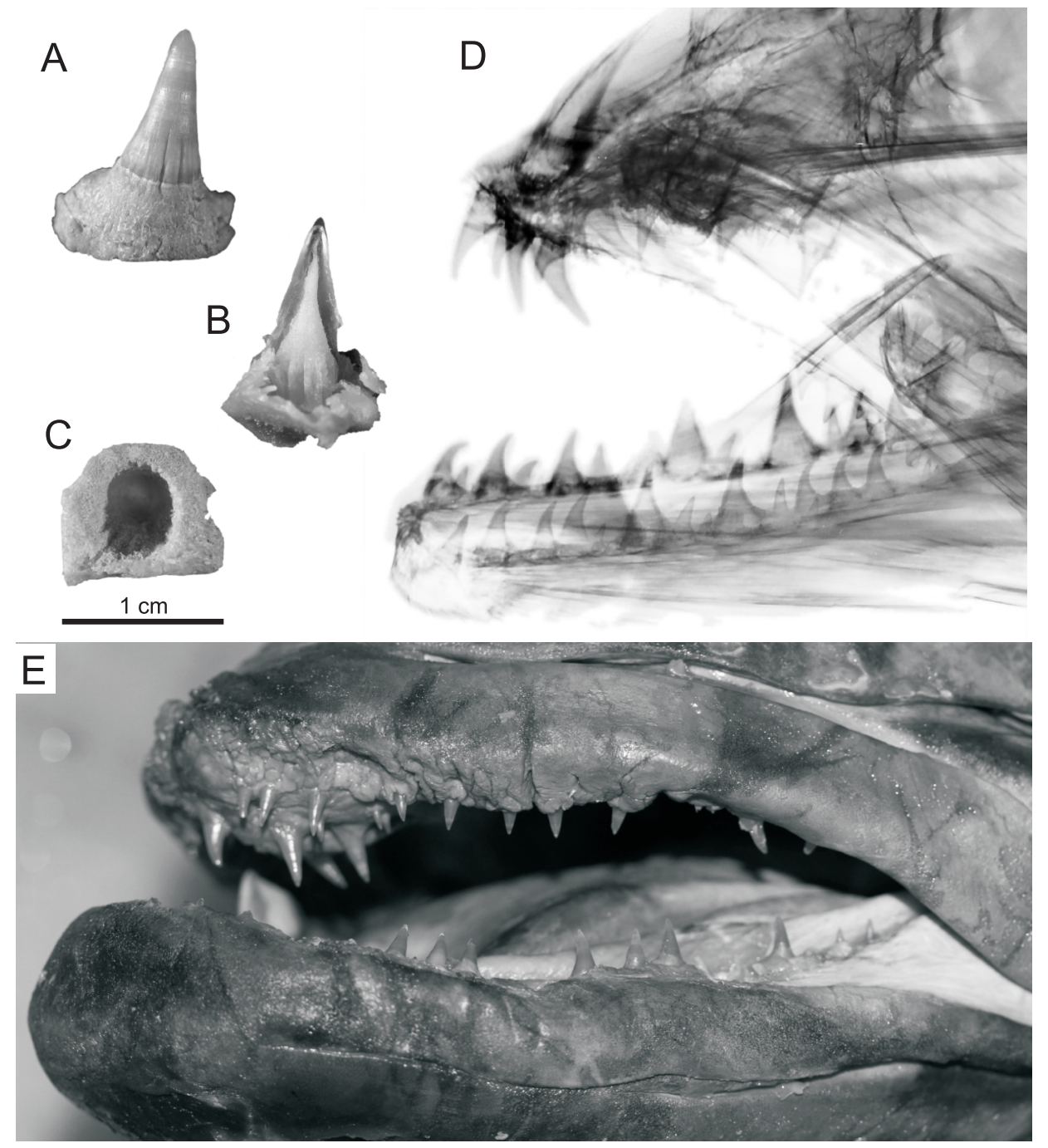

Fig. 15A-C - large teeth from the middle of left dentary and near the premaxillary symphysis of the huge Dissostichus eleginoides (ZMUC P632150, $180 \mathrm{~cm}, 70 \mathrm{~kg}$, wet specimen) in lateral view showing fissures and the pedicle like base, in section showing the "ridged" soft interior pulp, and from the base looking into the cavity with ridges on the wall; D-X-ray of the snout and jaws of a small $D$. eleginoides exposing large fangs near the premaxillary symphysis and in middle part of the dentary, which has smaller teeth at the symphysis (ZMUC P6341, $28 \mathrm{~cm} \mathrm{SL}$ ); E - jaws of Dissostichus eleginoides (ZMUC P632150, $180 \mathrm{~cm}$ ) showing distribution and size of teeth

Photographs by P.R. Møller

Near, 2004). The primitive nototheniid branch with Dissostichus has a minimum age of about $14 \mathrm{Ma}$ (Near, 2004), so that the $35 \mathrm{Ma}$ old Mesetaichthys could be in a stemgroup position to the AFGP notothenioids.

\section{CONCLUSIONS}

Jaw fragments of teleostean fishes and possibly a basioccipital and some vertebrae from the Late Eocene of the La Meseta Formation (Telm7) of Seymour Island are considered to be notothenioids (cod icefishes relatives among perciforms). Postulated "gadiform" features are shown to be dubious, apart from the open groove for the sensory canal in the lower jaw. This feature is seen in a few perciforms, but is not known in any living notothenioid.
The most well-preserved lower jaw fragment (Figs. 4, 5 and 6F) was selected as the holotype for Mesetaichthys jerzmanskae n. gen. and n. sp., a notothenioid incertae sedis - with premaxillary tooth bearing fragments as pararatypes. The diagnostic features are present in the dentition (which is remarkably similar to that of the big, predaceous nototheniid Dissostichus) in combination with the open groove for the sensory canal. The Mesetaichthys jerzmanskae n. gen. and n. sp. described here as notothenioid and a 10 m.y. older skull of Proeleginops grandeastmanorum Balushkin, 1994 described earlier also from the La Meseta Formation are the only fossil notothenioids recognized up to now.

\section{COMPARATIVE MATERIAL}

Recent Notothenioids, Natural History Museum of Denmark, University of Copenhagen, SNM. 
Nototheniidae: Notothenia microlepidota ZMUC uncat. (7495 - dry skeleton; Figs. 12E, F and 14A, B); Dissostichus eleginoides ZMUC P632150 (155 cm SL; Fig. 15; Møller et al., 2003: fig. 1), ZMUC P6341 (28 cm SL, X-ray; Fig. 15).

Chaenichthyidae: Chaenocephalus aceratus ZMUC uncat. (7741 - dry skeleton; Fig. 14E, F).

Eleginopsidae: Eleginops maclovinus ZMUC P63275 (84 mm SL, clear and stain); ZMUC CN 2 (365 mm SL, X-ray).

Recent Gadiforms (skeletons in Natural History Museum of Denmark, University of Copenhagen, SNM).

Merlucciidae: Merluccius merluccius Jrn. 215-217 (Figs. 13 and $14 \mathrm{C}, \mathrm{D}, \mathrm{G}, \mathrm{H}$ ).

Gadidae: Arctogadus glacialis ZMUC P371663, Boreogadus saisa CN 16, Brosme brosme Jrn. 28, Gadus morhua ZMUC P374478, P372971, Lota lota Jrn. 30 x, Melanogrammus aeglefinus Jrn. 301, Merlangus merlangus Jrn. 348, Molva molva Jrn. 58, Pollachius pollachius Jrn. 835, Trisopterus esmarkii ZMUC P3711, Trisopterus luscus Jrn. 9.

Phycidae: Phycis blennoides Jrn. 41, Urophycis brasiliensis Jrn. $30(\mathrm{I})$
Moridae: Antimora rostrata ZMUC uncat. (Ingolf exp.), Mora mora Jrn. 76.

Macrouridae: Coryphaenoides rupestris ZMUC uncat. (Skagerrak), Macrourus berglax Jrn. 15, Trachyrincus murrayi ZMUC P375081.

Recent Lophiiforms. Lophiidae: Lophius piscatorius ZMUC Jrn. 62.

Acknowledgements. Discussions with Dr. A.V. Balushkin (St. Petersburg) and Dr. J. Nielsen (Copenhagen) on the anatomy on notothenioids are very much appreciated. We are very grateful to reviewers Prof. J. Kriwet (Vienna) and Dr. $P$. Jadwiszczak (Białystok) whose comments have led to improvements of the manuscript. NB are very thankful to the Fur Museum for financial support to study-trips to the Institute of Paleobiology PAS, Warszawa. AG wishes to acknowledge the logistic support of the Instituto Antártico Argentino and Fuerza Aérea Argentina during the field work in Antarctica. Prof. A. Tatur (Warszawa) accompanied AG during field collection activities. K. Gregersen, Zoological Museum (Copenhagen) made skeletons of the notothenioids.

\section{REFERENCES}

Andersen N.C. (1984) Genera and subfamilies of the family Nototheniidae (Pisces, Perciformes) from the Antarctic and Subantartic. Steenstrupia, 10 (1): 1-34.

Arratia G., López-Arbarello A., Prasad G.V.R., Parmar V., Kriwet J. (2004) Late Cretaceous-Paleocene percomorphs (Teleostei) from India - early radiation of Perciformes. In: Recent Advances in the Origin and Early Radiation of Vertebrates (eds. G. Arratia, M.V.H. Wilson and R. Cloutier): 635-663. Verlag Dr. Friedrich Pfeil, München.

Balushkin A.V. (1984) Morphological bases for systematics and phylogeny of nototheniid fishes (in Russian with English summary). Zoologicheskiy Institut Akademii Nauk SSSR, Leningrad. Oxonian Press, New Delhi, India.

Balushkin A.V. (1992) Classification, phylogenetic relationships, and origins of the families of the suborder Notothenioidei (Perciformes). Journal of Ichthyology, 32 (7): 90-110.

Balushkin A.V. (1994) Proeleginops grandeastmanorum gen. et sp. nov. (Perciformes, Notothenioidei, Eleginopsidae) from the Late Eocene of Seymour Island (Antarctica) is a fossil notothenioid, not a gadiform. Journal of Ichthyology, 34 (8): $10-23$.

Balushkin A.V. (2000) Morphology, classification, and evolution of notothenioid fishes of the Southern Ocean (Notothenioidei, Perciformes). Journal of Ichthyology, 40 (Suppl. 1): 74-109.

Balushkin A.V., Voskoboinokova O.S. (1995) Systematics and phylogeny of Antarctic dragonfishes (Bathydraconidae, Notothenioidei, Perciformes). Journal of Ichthyology, 35 (5): 89-103.

Baumiller T.K., Gaździcki A. (1996) New crinoids from the Eocene La Meseta Formation of Seymour Island, Antarctic Peninsula. Palaeontologia Polonica, 55: 101-116.

Birkenmajer K., Gaździcki A., Krajewski K.P., Przybycin A., Solecki A., Tatur A., Yoon H.I. (2005) First Cenozoic glaciers in West Antarctica. Polish Polar Research, 26 (1): 3-12.

Błażejowski B., Gaździcki A., Małkowski K. (2010) Stable isotope composition of fish teeth from the Eocene La Meseta Formation of Seymour Island (Antarctica): paleoclimate and environmental proxies. Abstracts XXXI SCAR, Open Science Conference, Buenos Aires, Argentina 2010, Electronic version only.

Bonde N. (1987) Moler - its Origin and its Fossils Especially Fishes. Skamol, Nykøbing Mors, Denmark.
Bonde N. (1997) A distinctive fish fauna in the basal ash-series of the Fur/Ølst Formation (U. Paleocene, Denmark). Aarhus Geoscience, 6: 33-48.

Bonde N., Andersen S., Hald N., Jakobsen S.L. (2008) Danekrä Denmark's Best Fossils (in Danish). Gyldendal, Krbenhavn.

Bonde N., Madsen H., Schultz B., Sylvestersen R., Jakobsen S.L. (2011) Mo-clay in North Jutland - diatomite and fossils (in Danish). Dansk Naturhistorisk Forening, 19-20 (for years 2008-2010): 25-40.

Borsuk-Białynicka M. (1988) New remains of Archaeoceti from the Paleogene of Antarctica. Polish Polar Research, 9 (4): 437-445.

Cantrill D.J., Poole I. (2012) The Vegetation of Antarctica Through Geological Time. Cambridge University Press, Cambridge: UK.

Case J.A. (1992) Evidence from fossil vertebrates for a rich Eocene Antarctic marine environment. Antarctic Research Series, 56: $119-130$.

Case J.A. (2006) The late Middle Eocene terrestrial vertebrate fauna from Seymour Island: the tails of the Eocene Patagonian size distribution. Geological Society Special Publications, 258: 177-186.

Case J.A., Woodburne M.O., Chaney D.S. (1987) A gigantic phororhacoid (?) bird from Antarctica. Journal of Paleontology, 61: $1280-1284$

Casier E. (1966) Faune Ichthyologique du London Clay. 2 vols. British Museum (Natural History), London.

Cenizo M.M. (2012) Review of the putative Phorusrhacidae from the Cretaceous and Paleogene of Antarctica: new records of ratites and pelagornithid birds. Polish Polar Research, 33 (3): 239-258.

Cione A.L., Reguero M. (1994) New records of the sharks Isurus and Hexanchus from the Eocene of Seymour Island, Antarctica. Proceedings of the Geologists' Association, 105: 1-14.

Cione A.L., Reguero M. (1995) Extension of the range of Hexanchid and Isurid sharks in the Eocene of Antarctica and comments on the occurrence of Hexanchids in Recent waters of Argentina. Ameghiniana, 32 (2): 151-157.

Cione A.L., Reguero M. (1998) A Middle Eocene basking shark (Lamniformes, Cetorhinidae). Antarctic Science, 10 (1): 83-88.

Cione A.L., Aspelicueta M.M., Bellwood D. (1994) An Oplegnathid fish from the Eocene of Antarctica. Palaeontology, 37 (4): 931-940. 
Cione A.L., Reguero M., Elliot D.H. (2001) A large osteichthyan vertebra from the Eocene of Antarctica. Neues Jahrbuch für Geologie und Paläontologie Monatshefte, (9): 543-552.

Cione A.L., Reguero M., Acosta Hospitaleche C. (2007) Did the continent and sea have different temperatures in the Northern Antarctic Peninsula during the Middle Eocene? Revista de la Asociación Geológica Argentína, 62 (4): 586-596.

Claeson K.M., Eastman J.T., Macphee R.D.E. (2012) Definitive specimens of Merlucciidae (Gadiformes) from the Eocene James Ross Basin of Isla Marambio (Seymour Island), Antarctic Peninsula. Antarctic Science, 24 (5): 467-472.

Cohen D.M. (1984) Gadiformes: overview. American Society of Ichthyologits and Herpetologists, Special Publication, 1: 259-265.

Crame J.A. (1994) Evolutionary history of Antarctica. In: Antarctic Science (ed. G. Hempel): 188-214. Springer-Verlag, Berlin.

Dettaï A., Lecointre G. (2004) In search of notothenioid (Teleostei) relatives. Antarctic Science, 16 (1): 71-85.

Dingle R.V., Marenssi S., Lavelle M. (1998) High latitude Eocene climate deterioration: evidence from the northern Antarctic Peninsula. Journal of South American Earth Sciences, 11 (6): 571-579.

Doktor M., Gaździcki A., Marenssi S.J., Porębski S.J., Santillana S.N., Vrba A.V. (1988) Argentine-Polish geological investigations on Seymour (Marambio) Island, Antarctica, 1988. Polish Polar Research, 9 (4): 521-541.

Doktor M., Gaździcki A., Jerzmańska A., Porębski S.J., Zastawniak E. (1996) A plant-and-fish assemblage from the Eocene La Meseta Formation of Seymour Island (Antarctic Peninsula) and its environmental implications. Palaeontologia Polonica, 55: 127-146

Duhamel D., Gasco N., Davaine P. (2005) Poissons des îles Kerguelen et Crozet: guide régional de l'océan Austral. Collection Patrimoines Naturels, 63. Muséum national d'Histoire naturelle: Paris, France.

Dzik J., Gaździcki A. (2001) The Eocene expansion of nautilids to high latitudes. Palaeogeography, Palaeoclimatology, Palaeoecology, 17: 279-312

Eastman J.T. (2000) Antarctic notothenioid fishes as subjects for research in evolutionary biology. Antarctic Science, 12 (3): 276-287.

Eastman J.T., DeVries A.L. (1981) Buoyancy adaptations in a swim bladderless Antarctic fish. Journal of Morphology, 167 (1): 91-102.

Eastman J.T., Grande L. (1989) Evolution of the Antarctic fish fauna with emphasis on the Recent notothenioids. Geological Society Special Publications, 47: 241-252.

Eastman J.T., Grande L. (1991) Late Eocene gadiform (Teleostei) skull from Seymour Island, Antarctic Peninsula. Antarctic Science, 3 (1): 87-95.

Elliot D.H., Trautman W.J. (1982) Lower Tertiary strata on Seymour Island. In: Antarctic Geoscience (ed. C. Craddock). University of Wisconsin Press, Madison: 287-297.

Elżanowski A. (2003) Anna Jerzmańska (1928-2003). Acta Palaeontologica Polonica, 48 (1): 148.

Feldmann R.M., Woodburne M.O. (1988) Geology and paleontology of Seymour Island. GSA Memoir, 169: 1-566.

Fink W.L. (1981) Ontogeny and phylogeny of tooth attachment modes in actinopterygian fishes. Journal of Morphology, 167: 167-184.

Fostowicz-Frelik Ł. (2003) An enigmatic whale tooth from the Upper Eocene of Seymour Island, Antarctica. Polish Polar Research, 24 (1): 13-28.

Francis J.E., Pirrie D., Crame J.A., eds. (2006) Cretaceous-Tertiary High-Latitude Palaeoenvironments. Geological Society Special Publications, 258.

Francis J.E., Marenssi S., Levy R., Hambrey M., Thorn V.C., Mohr B., Brinkhuis H., Warnaar J., Zachos J., Bohaty S., DeConto R. (2009) From greenhouse to icehouse - the Eocene Oligocene in Antarctica. In: Developments in Earth and Environmental Sciences 8, Antarctic Climate Evolution (eds. F. Florindo and M. Siegert): 309-368. Elsevier, Amsterdam.
Gaździcki A., ed. (1996) Paleontological Results of the Polish Antarctic Expeditions, Part II. Palaeontologia Polonica, 55: 1-192.

Gaździcki A. (1998) Zespoły biotyczne i środowisko eocenu wyspy Seymour (Antarktyka). Kosmos, 47 (4): 417-424.

Gaździcki A., ed. (2001) Paleontological Results of the Polish Antarctic Expeditions, Part III. Palaeontologia Polonica, 60: 1-184.

Gaździcki A., Majewski W. (2012) Foraminifera from the Eocene La Meseta Formation of Isla Marambio (Seymour Island), Antarctic Peninsula. Antarctic Science, 24 (4): 408-416.

Gaździcki A., Gruszczyński M., Hoffman A., Małkowski K., Marenssi S.A., Hałas S., Tatur A. (1992) Stable carbon and oxygen isotope record in the Paleogene La Meseta Formation, Seymour Island, Antarctica. Antarctic Science, 4 (4): 461-468.

Gaździcki A., Tatur A., Hara U., Valle R.A. del (2004) The Weddell Sea Formation: post-Late Pliocene terrestrial glacial deposits on Seymour Island, Antarctic Peninsula. Polish Polar Research, 25 (3-4): 189-204.

Grande L., Eastman J.T. (1986) A review of Antarctic ichthyofaunas in the light of new fossil discoveries. Palaeontology, 29 (1): 113-137.

Gregory W.K. (1933) Fish Skulls. Fish skulls a study of the evolution of natural mechanisms. Transactions of the American Philosophical Society, 23 (1-2):75-481.

Iwami T. (1985) Osteology and relationships of the family Channichthyidae. Memoirs of National Institute of Polar Research. Ser. E, Biology and Medical Science, 36: 1-69.

Ivany L.C., Simaeys S. van, Domack E.W., Samson S.D. (2006) Evidence for an earliest Oligocene ice sheet on the Antarctic Peninsula. Geology, 34 (5): 377-380.

Ivany L.C., Lohmann K.C., Hasiuk F., Blake D.B., Glass A., Aronson R.B., Moody R.M. (2008) Eocene climate record of a high southern latitude continental shelf: Seymour Island, Antarctica. GSA Bulletin, 120 (5-6): 659-678.

Jadwiszczak P. (2006) Eocene penguins of Seymour Island, Antarctica: the earliest record, taxonomic problems and some evolutionary considerations. Polish Polar Research, 27 (4): 287-302.

Jadwiszczak P. (2009) Penguin past: the current state of knowledge. Polish Polar Research, 30 (1): 3-28.

Jadwiszczak P. (2010) Penguin response to the Eocene climate and ecosystem change in the northern Antarctic Peninsula region. Polar Science, 4 (2): 229-235.

Jadwiszczak P. (2012) Partial limb skeleton of a "giant penguin" Anthropornis from the Eocene of the Antarctic Peninsula. Polish Polar Research, 33 (3): 259-273.

Jadwiszczak P., Mörs T. (2011) Aspects of diversity in early Antarctic penguins. Acta Palaeontologica Polonica, 56 (2): 269-277.

Jerzmańska A. (1988) Isolated vertebrae of teleostean fishes from the Paleogene of Antarctica. Polish Polar Research, 9 (4): 421-435.

Jerzmańska A. (1991) First articulated teleost fish from the Paleogene of West Antarctica. Antarctic Science, 3 (3): 309-316.

Jerzmańska A., Świdnicki J. (1992) Gadiform remains from the La Meseta Formation (Eocene) of Seymour Island, West Antarctica. Polish Polar Research, 13 (3-4): 241-253.

Kriwet J. (2005). Additions to the Eocene selachian fauna of Antarctica with comments on Antarctic selachian diversity. Journal of Vertebrate Paleontology, 25 (1): 1-7.

Kriwet J., Gaździcki A. (2003) New Eocene Antarctic chimeroid fish (Holocephali, Chimaeriformes). Polish Polar Research, 24 (1): 29-51.

Kriwet J., Hecht T. (2008) A review of early gadiform evolution and diversification: first record of a rattail fish skull (Gadiformes, Macrouridae) from the Eocene of Antarctica, with otoliths preserved in situ. Naturwissenschaften, 95 (10): 899-907.

Lecointre G., Bonillo C., Ozouf-Costaz C., Hureau J.-C. (1997) Molecular evidence for the origins of Antarctic fishes: paraphyly of the Bovichtidae and no indication for the monophyly of the Notothenioidei (Teleostei). Polar Biology, 18 (3): 193-208.

Long D.J. (1991) Fossil cutlassfish (Perciformes: Trichiuridae) teeth from the La Meseta Formation (Eocene), Seymour Island, Antarctic Peninsula. Paleobios, 13: 3-4. 
Long D.J. (1992a) Sharks from the La Meseta Formation (Eocene), Seymour Island, Antarctic Penisula. Journal of Vertebrate Paleontology, 12: 11-32.

Long D.J. (1992b) Paleoecology of Eocene Antarctic sharks. American Geophysical Union, Washington, Antarctic Research Series, 56: 131-139.

Long D.J. (1992c) An Eocene wrasse (Perciformes, Labridae) from Seymour Island. Antarctic Science, 4: 235-237.

Marenssi S.A. (2006) Eustically crontrolled sedimentation recorded by Eocene strata of James Ross Bassin, Antarctica. Geological Society Special Publications, 258: 125-133.

Marenssi S.A., Casadio S., Santillana S.N. (2010) Record of Late Miocene glacial deposits on Isla Marambio (Seymour Island), Antarctic Peninsula. Antarctic Science, 22 (2): 193-198.

Marenssi S.A., Santillana S.N., Rinaldi C.A. (1998) Stratigraphy of the La Meseta Formation (Eocene), Marambio (Seymour) Island, Antarctica. Asociación Paleontológica Argentina, Publicación Especial, 5: 137-146.

Mitchell E.D. (1989) A new cetacean from the Late Eocene La Meseta Formation, Seymour Island, Antarctic Peninsula. Canadian Journal of Fisheries and Aquatic Science, 46: 2219-2235.

Moy-Thomas J.A. (1934) On the teeth of the larval Belone vulgaris, and the attachment of teeth in fishes. Quarterly Journal of Microscopical Science, 76 (3): 481-498.

Møller P.R., Nielsen J.G., Fossen I. (2003) Patagonian toothfish found off Greenland. Nature, 421: 599.

Mujib K.A. (1967). Cranial osteology of the Gadidae. Journal of the Fisheries Research Board, Canada, 24 (6): 1315-1375.

Myrcha A., Jadwiszczak P., Tambussi C.P., Noriega J.I., Gaździcki A., Tatur A., Valle R.A. del (2002) Taxonomic revision of Eocene Antarctic penguins based on tarsometatarsal morphology. Polish Polar Research, 23 (1): 5-46.

Near T.J. (2004) Estimating divergence times of notothenioid fishes using a fossil-calibrated molecular clock. Antarctic Science, 16 (1): 37-44.

Patterson C. (1993) Osteichthyes: Teleostei. In: The Fossil Record 2 (ed. M.J. Benton): 621-656. Chapman and Hall, London.

Porebski S.J. (1995) Facies architecture in a tectonically-controlled incised-valley estuary: La Meseta Formation (Eocene) of Seymour Island, Antarctic Peninsula. Studia Geologica Polonica, 107: 7-97.

Prokofiev A.M. (2007) The osteology of Bathysphyaenops symplex and the diagnosis of the Howellidae (Perciformes: Percoidei) family. Journal of Ichthyology, 47 (8): 566-578.

Rasmussen H.W. (1979) Crinoideos del Cretácico Superior y del Terciario interior de la Isla Vicecomodoro Marambio (Seymour Island), Antártida. Contribuciones científicas del Instituto Antártico Argentino 4: 79-96.

Regan C.T. (1914) British Antarctic (“Terra Nova”) Expedition 1910. Natural History Report, 1 (1): 1-54.

Reguero M.A., Marenssi S.A., Santillana S.N. (2002) Antarctic Peninsula and South America (Patagonia) Paleogene terrestial faunas and environments: biogeographic relationships. Palaeogeography, Palaeoclimatology, Palaeoecology, 179: 189-210.

Ritchie P., Lavoué S., Lecointre G. (1997) Molecular phylogenetics and the evolution of Antarctic notothenioid fishes. Comparative Biochemistry and Physiology, 118A (4): 1009-1025.

Rosen D.E., Patterson C. (1969) The structure and relationships of the paracanthopterygian fishes. Bulletin of American Museum of Natural History, 141 (3): 357-474.

Sadler P. (1988) Geometry and stratification of uppermost Cretaceous and Paleogene units of Seymour Island, northern Antarctic Peninsula. GSA Memoirs, 169: 303-320.

Schwarzhans W. (1980) Die tertiäre Teleosteer-Fauna Neuseelan ds, rekonstruiert anhand von Otolithen. Berliner Geowissenschaftliche Abhandlungen. Reihe A, Geologie und Paläontologie, 26: 1-211.

Schwarzhans W. (1981) Paläobiogeographische Analyse der tertiären Fischfauna von Neuseeland und Süd-Australien. Geologische Rundschau, 70 (2): 596-610.
Schwarzhans W. (1985) Tertiäre Otolithen aus South Australia und Victoria (Australien). Palaeo Ichthyologica, 3: 1-60.

Schwarzhans W. (2003) Fish otoliths from the Paleocene of Denmark. Geological Survey of Denmark and Greenland Bulletin, 2: 1-94.

Schwarzhans W. (2004) Fish otoliths from the Paleocene (Selandian) of West Greenland. Meddelelser om Grønland, Geoscience, 42: 1-32.

Simpson G.G. (1971) Review of the fossil penguins from Seymour Island. Proceedings of the Royal Society of London B, 178: 357-387.

Stilwell J.D., Zinsmeister W.J. (1992). Molluscan systematics and biostratigraphy. Lower Tertiary La Meseta Formation, Seymour Island, Antarctic Paninsula. Antarctic Research Series, 55. American Geophysical Union, Washington.

Svetovidov A.N. (1948) Fishes. Gadiformes. Fauna of the USSR. Zoologicheskiy Institut Akademia Nauk SSSR, 9 (4): 1-304. [Israel Program for Scientific Translation, National Science Found, Washington D.C. 1962].

Tambussi C.P., Noriega J.I., Gaździcki A., Tatur A., Reguero M.A., Vizcaino S.F. (1994) Ratite bird from Paleogene La Meseta Formation, Seymour Island, Antartica. Polish Polar Research, 15 (1-2): 15-20.

Tambussi C.P., Acosta Hospitaleche C.I., Reguero M.A., Marenssi S.A. (2006) Late Eocene penguins from West Antarctica: systematics and biostratigraphy. Geological Society Special Publications, 258: 145-161.

Tatur A., Gaździcki A., Valle R.A. del (2006) Might Cd/Ca ratio in bivalve shells mark a change in the Southern Ocean circulation at the Eocene/Oligocene boundary? SCAR 2nd Open Science Conference, SCAR XXIX/COMNAP XXVIII-2006, Hobart. CD, Poster 0588.

Tatur A., Krajewski K.P., Valle R.A. del (2011) The facies and biota of the oldest exposed strata of the Eocene La Meseta Formation (Seymour Island, Antarctica). Geological Quarterly, 55 (4): 345-360.

Uchman A., Gaździcki A. (2006) New trace fossils from the La Meseta Formation (Eocene) of Seymour Island, Antarctica. Polish Polar Research, 27 (2): 153-170.

Voskoboinikova O.S. (1994) Rates of individual skeleton development of bony skeleton of eleven species of the family Nototheniidae. Journal of Ichthyology, 34 (8): 108-119.

Voskoboinikova O.S. (1997) The osteological development of the Channichthyids (Notothenioidei). Cybium, 21 (4): 369-379.

Voskoboinikova O.S. (1998) Development of bony skeleton in early ontogeny of Harpagifer antarcticus (Harpagiferidae, Notothenioidei). Journal of Ichthyology, 38 (7): 501-510.

Voskoboinikova O.S., Bruce B. (2001) Development of bony skeleton during ontogeny of Bovichthys angustifrons (Bovichthyidae, Notothenioidei) with comparative notes on development of bony skeleton of Congolli Pseudaphritis urvilli (Pseudaphritidae). Journal of Ichthyology, 41: 62-71.

Ward D.J., Grande L. (1991) Chimeroid fish remains from Seymour Island, Antarctic Peninsula. Antarctic Science, 3 (3): 323-330.

Welton B.J., Zinsmeister W.J. (1980) Eocene neoselachians from the La Meseta Formation, Seymour Island, Antarctic Peninsula. Contributions in Science, Natural History Museum of Los Angeles County, 329: 1-10.

Woodburne M.O., Case J.A. (1996) Dispersal, vicariance and the Late Cretaceous to Early Tertiary land mammal biogeography from South America to Australia. Journal of Mammalian Evolution, 3 (2): 121-161.

Woodward A.S. (1908) On fossil fish remains from Snow Hill and Seymour Islands. Wissenschaftliche Ergebnisse der schwedischen Südpolar-Expedition 1901-1903, 3 (4): 1-4.

Zachos J., Pagani M., Sloan L., Thomas E., Billups K. (2001) Trends, rhythms, and aberrations in global climate $65 \mathrm{Ma}$ to present. Science, 292: 686-693. 